Discussion Paper No. 08-018

Who Gets the Money?

The Dynamics of

R\&D Project Subsidies in Germany

Birgit Aschhoff

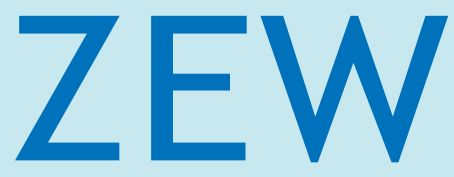

Zentrum für Europäische Wirtschaftsforschung $\mathrm{GmbH}$

Centre for European

Economic Research 


\section{Discussion Paper No. 08-018 \\ Who Gets the Money? \\ The Dynamics of \\ R\&D Project Subsidies in Germany}

Birgit Aschhoff
Download this ZEW Discussion Paper from our ftp server:
$\mathrm{ftp} / /$ ftp.zew.de/pub/zew-docs/dp/dp08018.pdf

ftp.//ftp.zew.de/pub/zew-docs/dp/dp08018.pdf

Die Discussion Papers dienen einer möglichst schnellen Verbreitung von neueren Forschungsarbeiten des ZEW. Die Beiträge liegen in alleiniger Verantwortung der Autoren und stellen nicht notwendigerweise die Meinung des ZEW dar.

Discussion Papers are intended to make results of ZEW research promptly available to other economists in order to encourage discussion and suggestions for revisions. The authors are solely responsible for the contents which do not necessarily represent the opinion of the ZEW. 


\section{Non-Technical Summary}

Each year over three thousand R\&D projects in more than two thousand firms received public grants from the German Federal Government. However, the number of subsidized firms does not reveal, whether it is always the same group of companies that receive funding, or whether the beneficiaries change over time. Understanding the temporal structure of subsidy distribution could help future research explain the effects and effectiveness of subsidies. In the face of shrinking government budgets and intensified international competition in the field of technology, knowing and increasing the efficiency of innovation policies has become crucial.

The focus is set on a specific public support scheme, the German Federal Government's non-defense R\&D project funding scheme (DPF). This is the most important tool used by the German government to fund R\&D in private businesses. In 2005, firms received over 700 million euros under this scheme. The importance of this funding scheme will increase in Germany in the coming years since it is the main distribution channel for the new High-Tech strategy launched by the Federal Government (BMBF, 2006b).

The aim of this paper is to analyze the structure of the firms receiving $R \& D$ subsidies over time. In particular, I tackle the question of whether the same firms enjoy subsidies over time. There is still very little empirical evidence on the dynamics of firms' participation in public funding schemes. In order to investigate the persistence of funding it is necessary to distinguish between two types of persistence. One is simply due to the fact that funded projects may run for more than one calendar year. The other is due to newly approved projects. In the DPF scheme, approved projects last on average for about three years.

The empirical part of this paper is based on an annual innovation survey, the German part of the Community Innovation Survey (CIS). This is merged with the DPF database in order to identify a firm's subsidy status in each year. The sample consists of over 6,000 different firms covering the manufacturing and knowledge-intensive service sectors over the time period from 1994 to 2004.

Transition rates are calculated which describe the participation in the DPF scheme between two periods in a univariate context. The share of innovating firms which enter the funding scheme is extremely low. But if a firm has made it into the DPF scheme, the probability of getting subsidies for new projects in the following year is higher than that of dropping out of the scheme. Overall, participation in the funding scheme is found to be quite stable. 
The multivariate analysis also shows that for the probability of getting new projects approved for the funding scheme, experience in the same scheme matters, beyond the subsidy status in the preceding year. In order to enter the DPF scheme, experience with other subsidy programs is also helpful. At the same time, it is important to control for the overall supply of subsidies. In addition, large firms are more successful in receiving funding for new projects. Thus the evidence cannot confirm that the scheme is achieving the government's aim of supporting SMEs in particular. The hypotheses that firms with higher knowledge capabilities are more likely to enter and stay in the scheme can be supported as I found positive impacts of R\&D activities and human capital. 


\section{Das Wichtigste in Kürze (Summary in German)}

In den meisten OECD-Ländern fördert der Staat Forschungsaktivitäten der Unternehmen, um damit die Innovationskraft und Wettbewerbsfähigkeit zu stärken. In Deutschland ist das wichtigste Instrument des Bundes für die finanzielle Förderung von FuE-Tätigkeiten in der Wirtschaft die direkte Projektförderung (DPF). Diese Maßnahme fördert im Rahmen von Fachprogrammen FuE-Projekte mittels nicht zurückzahlbarer Zuschüsse, die in bestimmten Schlüsseltechnologien angesiedelt sind. Im Rahmen der DPF werden jedes Jahr über 3.000 FuE-Projekte in über 2.000 Unternehmen gefördert. 2005 erhielten die Unternehmen auf diesem Wege über 700 Millionen Euro. Die DPF gewinnt durch die Hightech Strategie des Bundes weiter an Bedeutung.

Informationen über die Anzahl der geförderten Unternehmen geben jedoch noch keinen Aufschluss über die Struktur der Zuwendungsempfänger im Zeitverlauf, d.h. ob die Zusammensetzung der geförderten Unternehmen eine hohe Dynamik aufweist. Aber gerade die zeitliche Struktur spielt unter Umständen eine wichtige Rolle bei der Beurteilung der Auswirkungen der Förderung.

Daher ist das Ziel dieser Studie, die Teilnahme der Unternehmen an der DPF hinsichtlich der zeitlichen Struktur empirisch zu analysieren. Die Untersuchung basiert auf dem Mannheimer Innovationspanel, einer jährlich durchgeführten Innovationserhebung. Dieser Datensatz wurde mit Informationen der DPF-Datenbank ergänzt, um den Förderstatus der Unternehmen in jedem Jahr zu identifizieren. Der Datensatz für die Untersuchung besteht aus über 6.000 verschiedenen Unternehmen aus dem Verarbeitendem Gewerbe und Dienstleistungssektor.

Im ersten Schritt werden Übergangswahrscheinlichkeiten berechnet, die die Teilnahme der Unternehmen an der DPF in zwei aufeinander folgenden Jahren beschreiben. Dabei erweist sich der Anteil der Unternehmen, die neu an der DPF teilnehmen, als extrem klein. Wenn jedoch ein Unternehmen bereits an der DPF partizipiert, ist die Wahrscheinlichkeit höher, weiterhin neu geförderte Projekte zu bekommen, als aus der Förderung auszuscheiden. Insgesamt kann die Teilnahme an der Maßnahme als recht stabil beurteilt werden. Die darauf aufbauende multivariate Untersuchung zeigt ferner, dass die Wahrscheinlichkeit ein neues Projekt genehmigt zu bekommen, nicht nur vom Förderstatus im vorhergehenden Jahr abhängig ist, sondern mit der Erfahrung insgesamt im Programm steigt. Um an der DPF zu partizipieren, spielt auch die Erfahrung mit anderen Fördermaßnahmen eine positive Rolle. Außerdem sind große Unternehmen erfolgreicher neu an der DPF teilzunehmen und auch weitere Projekte gefördert zu bekommen. Die Hypothese, dass Unternehmen mit besseren Fähigkeiten in Bezug auf Wissenserzeugung und -management mit einer höheren Wahrscheinlichkeit neu und auch länger an der DPF teilnehmen, kann bestätigt werden, da FuE-Aktivitäten und Humankapital jeweils einen positiven Einfluss ausüben. 


\title{
Who Gets the Money? \\ The Dynamics of R\&D Project Subsidies in Germany
}

\author{
Birgit Aschhoff ${ }^{1}$
}

March 2008

\begin{abstract}
The question of the allocation of public R\&D funding is becoming particularly important when it comes to identifying the effects of state subsidies, in terms of input or output additionality. This analysis goes one important step further than the existing literature by including the time dimension. Using firm-level data on German manufacturing and knowledge-intensive service firms, this paper sheds light on the structure of the subsidy recipients over time. It turns out that participation in the funding scheme is quite stable. This is also confirmed by applying a multivariate approach. Firms having received funding in the past are more likely to be selected for public funding again. It is also important to control for the overall supply of subsidies. Besides, a firm's size and knowledge capabilities increase the probability of entering the scheme.
\end{abstract}

Keywords: R\&D, Public Subsidies, Program Participation, Germany

JEL Classification: C20, H32, O38

Address: $\quad$ Centre for European Economic Research (ZEW)

Department of Industrial Economics and International Management P.O.Box 1034 43, 68304 Mannheim, Germany

Phone: $\quad+49 / 621 / 1235-182$

E-Mail: aschhoff@zew.de

\footnotetext{
${ }^{1}$ I am grateful to the Federal Ministry of Education and Research for providing the data. I thank Christian Rammer, Irwin Feller, Ulrich Kaiser, Georg Licht, Bettina Peters, and the participants of the $5^{\text {th }}$ annual IIOC (2007) in Savannah, the Economics of Technology Policy Conference at Monte Verità (2007), the $10^{\text {th }}$ EUNIP International Conference (2007) in Prato and the CONCORD (2007) in Seville for helpful comments and suggestions. Financial support from the Anglo-German Foundation is gratefully acknowledged.
} 


\section{Introduction}

Each year over three thousand $R \& D$ projects in more than two thousand firms received public grants from the German Federal Government. ${ }^{2}$ However, the number of subsidized firms does not reveal, whether it is always the same group of companies that receive funding, or whether the beneficiaries change over time. A first question which arises is how the public subsidies are allocated across firms over time.

The question of the allocation of public R\&D funding across firms takes on a particular importance when it comes to identifying the microeconomic effects of subsidies with respect to input or output additionality. In order to answer the question appropriately, a potential bias needs to be controlled for. Many studies begin by determining a firm's probability of receiving a subsidy. For this purpose it is necessary to know in detail how specific schemes allocate subsidies in practice. Understanding the temporal structure of subsidy distribution could help future research explain the effects and effectiveness of subsidies. In the face of shrinking government budgets and intensified international competition in the field of technology, knowing and increasing the efficiency of innovation policies has become crucial.

The aim of this paper is to analyze the structure of the firms receiving $R \& D$ subsidies over time. There is still very little empirical evidence on the dynamics of firms' participation in public funding schemes. In the empirical literature there are several studies which include an analysis of firms' subsidy participation. However there are only a few papers which consider the subsidies over time, by at least controlling for the experience of applying for or receiving public awards. These are the studies by Feldman and Kelley (2001), Duguet (2004), González, Jaumandreu and Pazó (2005), and Tanayama (2007). Overall, it seems that firm's subsidy histories have an impact on obtaining awards in the future.

A lot of subsidy programs are available on the regional, national and European level which might have different allocation rules due to different goals and eligibility criteria. Thus, it is important to distinguish in the analysis between these programs. This means an analysis should concentrate on one specific programme in order to get useful results. ${ }^{3}$ The focus on specific funding schemes is lacking in most empirical studies. Often data from firms subsidized under a number of different schemes are examined. Another issue is the length of the period over which a single award is distributed to a firm. Since subsidies are often granted for projects that run over several years the persistence of subsidies will

\footnotetext{
${ }^{2}$ Own calculations based on the PROFI database. The database is described in section 4 .

${ }^{3}$ Blanes and Busom (2004) found differences between the participating firms in national and regional programs.
} 
be over-estimated if this fact is not taken into account. I extend the literature by considering these two issues in this study.

This analysis goes one important step further than the existing empirical literature by focussing on the time dimension. The focus is set on a specific public support scheme, the German Federal Government's non-defense R\&D project funding within thematic programmes (DPF). This is the most important tool used by the German government to fund R\&D in private businesses. In 2005, firms received a total of 745 million euros under this scheme. (BMBF, 2006a, pp. 188f. $)^{4}$ The importance of this funding scheme will increase in Germany in the coming years since it is the main distribution channel for the new HighTech strategy launched by the Federal Government (BMBF, 2006b). In the DPF scheme a subsidy is granted for three years on average. The duration of each project is known and is considered in the analysis.

In this study, more detailed knowledge of the actual pattern and dynamics of public R\&D funding is obtained. In particular, I tackle the question of whether the same firms enjoy subsidies over time, which would mean that there is, to some extent, a pool of firms which are funded continuously, i.e. a certain clientele benefits from state funding permanently. Alternatively one may expect the composition of subsidized firms to be highly dynamic, thanks to a steady entry into and exit from the subsidy scheme at the firm level, so that the funded firms change continuously. The causality between the subsidy allocation and the effects it induces is however beyond the scope of this paper.

The paper is organized as follows. The next section outlines the arguments, aims, and mechanisms of direct $R \& D$ project subsidies delivered by the Federal Government of Germany in the framework of thematic R\&D programs. Section 3 reviews the empirical literature concerning firms' participation in R\&D subsidy programmes. The subsequent section depicts some stylized facts on the structure of the recipients of the German DPF scheme over time. The focus is on distinguishing whether the firms involved are subsidized for the first time or whether they have received funding under the DPF scheme previously. The data set underlying the empirical analysis is described in section 5. The data used is based on an annual innovation survey, the German part of the Community Innovation Survey (CIS). This is merged with the German Federal Government's DPF database producing a total of 6,360 different firms over the time period from 1994 to 2004. Results of a descriptive analysis of subsidized and not subsidized firms are shown. The funding scheme is then examined in a multivariate context with means of markov chains. The econometric model and the estimation results are presented in section 6 , before drawing conclusions in section 7 .

\footnotetext{
${ }^{4} 448.5 \mathrm{~m}$ euros were given by the the Federal Ministry of Education and Research, 296.1m euros by the Federal Ministry of Economics and Technology.
} 


\section{The Direct Project Funding (DPF) Scheme}

\section{Rationale, Objectives and Mechanisms}

The German Federal government supports the view that in a market economy competition makes sure that new products and processes are generated and that demand potentials and profit opportunities are ascertained by the companies. Even though companies are responsible for their own R\&D and innovation decisions, nevertheless, the government also states that public support can make sense. Due to external effects of R\&D, incentives for companies might be too low in order to conduct R\&D on a level that would be desirable from a welfare point of view (BT-Drs., 1988, p. 43). The externalities of R\&D lead to the problem that leaking knowledge increases social returns but reduces private returns. If $\mathrm{R} \& \mathrm{D}$ generates higher social than private returns, the level of $R \& D$ activities in the economy in question is below the socially desirable level (see Levin, Klevorick, Nelson and Winter, 1987; Adams and Jaffe, 1996). Public support should increase private $R \& D$ investment to the socially optimal level. In addition the government argues that public support of $R \& D$ related to public goods like, for example, the quality of air or water, is justified due to the lack of corresponding markets. Other reasons for state aid for private R\&D can be an extremely long time horizon of R\&D projects, high economic or technical risk, or extremely high costs which one firm alone cannot bear (BT-Drs., 1984, p. 28; BT-Drs., 1988, p. 43; BT-Drs., 1993, p. 17).

The German government employs a variety of instruments in its R\&D policy, for example, institutional funding, indirect and direct support schemes. Depending on the objectives pursued, different instruments are used. In cases when a selective solution is aimed at and other support instruments are insufficiently target-oriented, too intricate, or a cross-industry key technology is targeted, direct $\mathrm{R} \& \mathrm{D}$ project funding is used (BT-Drs., 1984, pp. 28, 64). The overall objective of this support scheme is to achieve a high level economic performance and competitiveness of R\&D in selected areas (BT-Drs., 1984, p. 14; BMBF, 2000, p. 55).

Direct R\&D project funding (DPF) has existed since the mid 1950s and began with the public funding of large-scale $R \& D$ projects in the field of nuclear research. In the 1960s, funding was extended to other technological fields, such as space research or data processing. Besides major research institutions and universities large firms were also subsidized. At the end of the 1970s the group of recipients was extended to include SMEs (Fier, 2002). Funding of collaborative projects has been emphasized within direct $R \& D$ project funding since the 1980 s. The DPF scheme has become the most important tool used by the national government to support private businesses' R\&D. Therefore, the focus in this paper is set on this tool. 
The DPF scheme offers grant aid funding for R\&D projects in predefined fields of technology, for example, biotechnology, sustainable development, information technology, and materials research. The fields of technology are selected by the government and the financial support is thematically restrictive to these technologies. Within the technology fields several programs are defined which include funding objectives and rules. These programs run for several years, are made public in calls and applications have to be made within defined dates. Both companies and research institutions - or both together in a joint project - submit project-based applications for funding. In most programs, applications based on a cooperation of firms and research institutions are recommended though not obligatory. Program agencies authorized by the government and responsible for specific thematic areas decide on the application. The scheme itself does not specify a maximum permissible proportion of recipients that have already received funding. The criteria for approving a project do not differ between firms that have already participated in the scheme and firms which want to participate for the first time. ${ }^{5}$ The funding is granted on a cost sharing basis. Up to 50 percent of the R\&D project costs are covered by the government. Thus, the funding directly reduces firms' R\&D costs.

Within the empirical analysis, an issue arises due to the mechanisms of the subsidy allocation process. The allocation of subsidies is based on a multi-stage decision-making process. First of all, the company needs to be aware of the program in order to apply. Secondly, before submitting a proposal it is mostly recommended in the guidelines of the funding programs that companies should contact the program agency. Communication with the program agency may lead to a withdrawal or redesign of the application. Finally, the application can be rejected by the agency. Thus, there are several points at which the application process can be broken off.

The government does not report data on this issue, such as rejection rates or the share of applications being withdrawn by the applicant after contacting the program agency (BT-Drs., 2005, p. 8). Therefore, we cannot differentiate between applications, not made due to the ignorance of the company or due to a preliminary discussion with the program agency and also between applications which were withdrawn by the company or applications which were rejected by the program agency. A similar problem occurs in many other studies. ${ }^{6}$

\section{Hypotheses for Empirical Analysis}

The government states in its program guidelines that public financial support to firm R\&D should be only temporary. "Support programmes run for several years.

\footnotetext{
${ }^{5}$ In contrast, e.g., within the SBIR program additional criteria apply "for the evaluation of SBIR applications of firms which had received awards in the past." (Lerner, 1999, p. 304)

${ }^{6}$ The only exceptions are studies for Finland, such as e.g. Ali-Yrkkö (2005) or Tanayama (2007), since rejected applications are known.
} 
It is important that they be properly balanced: On the one hand, applications need a certain amount of time in order to reach maturity; on the other hand, they should not become permanently dependent on support." (BMBF, 2005, p. VI) A permanent alimentation of specific research areas and thus of firms is not intended (BT-Drs., 1979, p. 28; BMBF, 2004, p. VI).

The first question to analyze is whether some firms receive subsidies permanently. Though the intention of the government is not to support firms permanently, there are several reasons why firms might be receiving steady support. First, firms which have participated in the scheme might realize learning effects. They can use their experience for submitting a successful application. They might also be better able to rate which $R \& D$ projects might be suitable for funding. In addition, the transaction costs might be less for them since the effort for submitting a (additional) proposal is smaller. Secondly, due to asymmetric information, not all eligible firms are aware of the funding opportunity and do not submit an application. Therefore, the probability of receiving subsidies is higher for firms which have successfully applied for funding in the past. And firms which have already participated in the support scheme might know the support opportunities better than the other firms. Third, a firm may have specific characteristics which increase its probability of success or belong to a group of firms which enjoy priority treatment by the government, e.g., because of their location, sector activity or technology specialization.

Since the funding programs run for several years and considering the argumentation in favor of a more stable participation pattern, it is assumed that a rather persistent participation pattern will be found.

Program agencies' decisions are based on the proposed R\&D projects, not on firm characteristics. But information on the project-level is not available for not subsidized projects. However, it can be analyzed which firms had submitted the best applications and got the grants. Thus the second question to answer is which type of firms can be found as participants and are thus actually addressed by the government's subsidy program. Looking at the government's reasoning for running the DPF scheme, i.e. funding of R\&D projects with high economic and technical risk, long time horizon, and budget requirements that go beyond the capabilities of a single firm and which not would have been carried out without the public support, it can be assumed that this applies more likely to small and young firms due to their limited resources. Thus the probability that applications from these firms are selected and approved by the program agency should be higher.

Another reason why smaller firms are more likely to be chosen by program agencies is that small and medium-sized enterprises (SME) have become a key 
target group of innovation policy in Germany. The Federal government states that one main area of the promotion of industry lies in the promotion of SMEs (BMBF, 2004, p. 203). They have started activities which focus on promoting and supporting SMEs. For instance, they launched an initiative entitled 'Innovation and Future Technologies for Medium-Sized Companies - High-Tech Master Plan' in the year 2004 (BMBF and BMWA, 2004). Even in the direct R\&D funding scheme special attention is paid to SMEs. The probability that program agencies approve project proposals should be higher for SMEs.

On the other hand large firms may have information advantages because they are able to provide more resources for tracing funding opportunities, since the costs can be spread over more revenues. Therefore, large firms may have a higher probability of applying to R\&D funding schemes. Thus size is expected to be an important variable in explaining the participation in the public support program, although the direction of the impact is ambiguous.

The final goal of the government when offering subsidies to firms is to increase their competitiveness. Program agencies might think that certain firms are more capable of achieving this and favor more experienced and capable firms or firms which are already on a high level or on a promising path (picking-the-winner strategy). Thus regular R\&D activities and human capital might positively influence the agencies' decisions. Furthermore, firms with a high patent stock compared to other firms in their industry might be in a more favorable position to achieve international competitiveness and thus have the advantage of being awarded by the agencies. Furthermore, firms which grew in the past might be more likely to be successfully selected in the program. If the firm is subsidized in the previous years, this growth can be also an effect of the previous support. This could be an indicator that the project had a positive effect and the firm might have an advantage to get further projects granted. 


\section{Previous Empirical Studies}

In the empirical literature there are several studies which include an analysis of firms' participation in public R\&D programs. This is often related to investigating the effects of public funding on firms' R\&D inputs or outputs. In order to analyze this question appropriately a potential selection bias has to be taken into account. For this purpose the determinants of receiving public funding have to be analyzed. There are only a few papers however, which consider receiving subsidies over time by at least including a variable for the experience with public awards.

Duguet (2004) is one of these exceptions. He looks at the subsidy status at the firm-level in two consecutive years within the time period between 1985 and 1997 and identifies the entries and exits. The overall receipt of R\&D subsidies from any national ministry is taken into account. About a quarter of the firms are subsidized in two consecutive years whereas about 60 percent are not subsidized in the previous and current year. The entry and exit rates vary between 5 and 9 percent per year. Thus, he concludes that the stability of recipients in his sample is rather strong. Applying a logit model in order to estimate the probability of receiving subsidies, he finds that both the former receipt of subsidies and the average amount of subsidies have a significantly positive effect. The study does not control, however, whether the same granting is responsible for the subsidization of a firm in two consecutive years, i.e. once approved, a subsidy is given in more than one calendar year. The influence of experience is overestimated in such a case since firms detected as receiving funding in year $t+1$ are simply continuing funded projects started in the previous year.

In the first part of their study, Feldman and Kelley (2001) investigated factors influencing the decision to grant an Advanced Technology Program (ATP) award in 1998. In a logit model explaining winning an ATP award the two variables concerning ATP experience, first-time application to ATP and number of previous ATP awards, had no significant effect. Looking at the descriptive statistics of these two variables it becomes apparent that they are fairly similar and probably highly negatively correlated. ${ }^{7}$ Maybe including only the first-time application dummy would have shown a significant effect.

González et al. (2005) analyzed the effects of R\&D subsidies on R\&D performers and non-performers using a unbalanced panel data set of Spanish manufacturing firms. They aggregate subsidies from varies sources, such as regional, national and EU programs and do not distinguish between them. In a first step

\footnotetext{
${ }^{7}$ The means of the first-time application dummy and the number of prior ATP awards are 0.5 and 0.56 , respectively. Considering that one firm had 12 prior awards, it results that only between 1 and 5 further firms had more than one prior award.
} 
they estimate firms' expectations of subsidies by applying a probit model for the probability of receiving a subsidy and an OLS model for the amount. Besides other firm characteristics, they take into account the receipt of subsidies in the preceding one or two periods. They found that the subsidy dummies lagged by one period and by two periods both have a significantly positive influence on the receipt of a subsidy.

Tanayama (2007) focuses in her study on the application process for R\&D subsidies by the Finish Funding Agency for Technology and Innovation (Tekes) via the number of filed applications between 2000 and 2002. Using a zero-inflated negative binomial model, she found that the number of applications before 2000 increases both the probability of being a potential applicant for the subsidy scheme (binary process) and the number of filed applications conditional on being a potential applicant (count process).

Several studies have investigated the participation pattern in subsidy programs. An overview of empirical studies analyzing the probability of receiving subsidies is shown in table 1. Only a few of them have controlled for a potential effect of subsidy experience or prior participation in subsidy schemes. It seems that a firm's subsidy history has an impact on further awards, but it is not unambiguous. In most studies, analysis of experience effects are not program specific, but rather aggregate regional, national and European-wide program participation into one single experience measure. But allocation rules differ between programs as it was shown in a study by Blanes and Busom (2004). All of the studies except the one by Feldman and Kelley (2001) and Tanayama (2007) have neglected that a subsidy is often given for longer time period than one year. Thus they did not control for whether a subsidy was newly granted or continued and the identified effect might be thus overestimated. Among other things, this review makes it clear that firm-level empirical evidence on persistence in participation of subsidy programs is rather scarce and not very detailed. I want to contribute to this literature by controlling for the two mentioned shortcomings. I focus on one specific support scheme - the DPF scheme - and take into account the duration of the subsidized projects to correct for a bias due to longer lasting projects. In the next section the DPF scheme is described in detail. 
Table 1: Overview of Empirical Studies

\begin{tabular}{|c|c|c|c|c|c|}
\hline Authors & Country & $\begin{array}{l}\text { Data (Sector; refer- } \\
\text { ence period; number of } \\
\text { observations) }\end{array}$ & Estimation Method $^{a}$ & Program & Significant variables $^{b}$ \\
\hline Feldman and Kelley (2001) & USA & $\begin{array}{l}\text { Mainly manufacturing }{ }^{c} \text {; } \\
\text { 1998; } 239\end{array}$ & logit & $\begin{array}{l}\text { Advanced Technology } \\
\text { Program }\end{array}$ & $\begin{array}{l}\text { +existing linkages to other businesses, +openness regard- } \\
\text { ing results, + +new partnerships in project, + +new technical } \\
\text { area in project, +maximum score on reviewers' rating of } \\
\text { technical plan, +maximum score on reviewers'rating of } \\
\text { business plan \& economic potential }{ }^{d}\end{array}$ \\
\hline Duguet (2004) & France & $\begin{array}{l}\text { Manufacturing and ser- } \\
\text { vice; } 1985-1997 ; 16,776\end{array}$ & $\operatorname{logit}^{e}$ & $\begin{array}{l}\text { no specific program; } \\
\text { national R\&D subsi- } \\
\text { dies from all min- } \\
\text { istries }\end{array}$ & 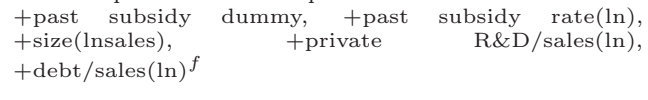 \\
\hline González et al. (2005) & Spain & $\begin{array}{l}\text { Manufacturing; } 1990- \\
1999 ; 9,455 \text { (2,214 firms) }\end{array}$ & $\begin{array}{lrl}\text { probit } & \text { (in } & \text { second } \\
\text { step: } & \text { tobit } & \text { for } \\
\text { sidy amount) }\end{array}$ & $\begin{array}{l}\text { no specific program; } \\
\text { regional, national, EU } \\
\text { programs aggregated }\end{array}$ & $\begin{array}{l}\text { +subsidy dummy lagged one and two periods, - abnormal } \\
\text { subsidy dummy, +size (emp) lagged, +age, +technologi- } \\
\text { cal sophistication, +capital growth, +domestic exporter } \\
\text { dummy lagged, +foreign capital dummy }\end{array}$ \\
\hline Tanayama (2007) & Finland & $\begin{array}{l}\text { Manufacturing and know- } \\
\text { ledge intesive service; } \\
2000-2002 ; 12,275\end{array}$ & $\begin{array}{l}\text { count data model (zero- } \\
\text { inflated negative bino- } \\
\text { mial) for no. of applica- } \\
\text { tions }\end{array}$ & $\begin{array}{l}\text { Finnish } r \text { Funding } \\
\text { Agency for Technol- } \\
\text { ogy and Innovation } \\
\text { (Tekes) }\end{array}$ & $\begin{array}{l}\text { binary and count process: }+ \text { no. prior applications, }- \text { no. } \\
\text { prior applications }{ }^{2},+ \text { size }(\operatorname{lnemp}),+ \text { no. board members; } \\
\text { only binary: +export dummy; only count: -age, + } \text { age }^{2}, \\
\text {-sales/emp }(\ln ),+ \text { sales } / \text { emp }^{2}, \text { + + parent company }\end{array}$ \\
\hline Busom (2000) & Spain & Manufacturing; $1988 ; 147$ & $\begin{array}{l}\text { probit (used in Heck- } \\
\text { man's two step model for } \\
\text { R\&D effort) }\end{array}$ & $\begin{array}{l}\text { no specific program; } \\
\text { national or European } \\
\text { programs separately }\end{array}$ & $\begin{array}{l}- \text { size }(e m p),+ \text { age, }- \text { patents obtained over last } 10 \text { years, } \\
\text {-foreign ownership } g\end{array}$ \\
\hline Wallsten (2000) & USA & $\begin{array}{l}\text { Manufacturing and ser- } \\
\text { vice; 1990-1992; } 481\end{array}$ & $\begin{array}{l}\text { 3-Stage Least Squares; } \\
\text { 1st (2nd) stage: Number } \\
\text { Phase } 1(2) \text { A wards }\end{array}$ & $\begin{array}{l}\text { SBIR, Phase } 1 \text { and } \\
\text { Phase } 2 \text { awards }\end{array}$ & + SBIR budget, + prior patent applications \\
\hline Czarnitzki and Fier (2002) & Germany & $\begin{array}{l}\text { Service; } 1994-1996 \quad \& \\
1996-1998 ; 1,084\end{array}$ & probit $^{e(t)}$ & $\begin{array}{l}\text { no specific program; } \\
\text { local, national, EU } \\
\text { programs agregated }\end{array}$ & $\begin{array}{l}\text { +size(lnemp), + +location in Eastern Germany, + } \text { continu- } \\
\text { ous R\&D, +share of emp. with univ. degree in business } \\
\text { admin. /economics etc. - districts population density }\end{array}$ \\
\hline $\begin{array}{l}\text { Almus and Czarnitzki } \\
(2003)\end{array}$ & $\begin{array}{l}\text { Eastern } \\
\text { Germany }\end{array}$ & $\begin{array}{ll}\text { Manufacturing; } & 1992- \\
1994, \quad 1994-1996, & 1996- \\
1998: 925\end{array}$ & probit $^{e}$ & $\begin{array}{l}\text { no specific program; } \\
\text { local, national, EU } \\
\text { programs agoregated }\end{array}$ & $\begin{array}{l}\text { +size(lnemp), - foreign parent company, - - sellers concen- } \\
\text { tration, +R\&D department }\end{array}$ \\
\hline $\begin{array}{l}\text { Aerts } \text { and Czarnitzki } \\
(2004)\end{array}$ & Belgium & $\begin{array}{l}\text { Manufacturing \& service; } \\
\text { 1998-2000; } 776\end{array}$ & probit $^{e}$ & $\begin{array}{l}\text { no specific program; } \\
\text { local, national, EU } \\
\text { programs aggregated }\end{array}$ & $\begin{array}{l}\text { +size(lnemp), +patentstock/emp., } \quad-\text { foreign parent } \\
\text { comp., +export }\end{array}$ \\
\hline Blanes and Busom (2004) & Spain & $\begin{array}{l}\text { Manufacturing; } 1990- \\
1996 ; 15,186 \text { (463 differ- } \\
\text { ent subsidized firms) }\end{array}$ & $\begin{array}{l}\text { multinomial logit } \text { (no } \\
\text { R\&D; R\&D, no par- } \\
\text { ticipation; R\&D and } \\
\text { participation), bivariate } \\
\text { probit (national and } \\
\text { regional program) }\end{array}$ & $\begin{array}{l}\text { no specific program; } \\
\text { regional and national } \\
\text { programs aggregated }\end{array}$ & $\begin{array}{l}\text { +size }(\mathrm{emp}),+ \text { domestic; only nat.: +human capital; only } \\
\text { reg.: }- \text { cash flow }{ }^{i}\end{array}$ \\
\hline $\begin{array}{l}\text { Czarnitzki, Ebersberger } \\
\text { and Fier (2004) }\end{array}$ & $\begin{array}{l}\text { Western } \\
\text { Germany \& } \\
\text { Finland }\end{array}$ & $\begin{array}{l}\text { Manufacturing \& service; } \\
\text { 1994-1996 \& } 1998-2000 \\
\text { DE: } 1,464 ; \text { FI: } 1,520\end{array}$ & $\begin{array}{l}\text { multinomial probit (sub- } \\
\text { sidization, collaboration, } \\
\text { both) })^{e}\end{array}$ & $\begin{array}{l}\text { no specific program; } \\
\text { local, national, EU } \\
\text { programs aggregated }\end{array}$ & $\begin{array}{l}\text { +size(lnemp), +share of R\&D emp., +lagged patent ap- } \\
\text { plication; only FI: +export }\end{array}$ \\
\hline $\begin{array}{l}\text { Czarnitzki and Licht } \\
(2006)\end{array}$ & Germany & $\begin{array}{l}\text { Manufacturing; } 1992- \\
1994 \& \text { \& 1994-1996 \& } \\
1996-1998 \& \text { \& } 1998-2000 ; \\
6,462 \text { (3,409 R\&D per- } \\
\text { forming firms) }\end{array}$ & probit $^{e}$ & $\begin{array}{l}\text { no specific program; } \\
\text { local, national, EU } \\
\text { programs aggregated }\end{array}$ & 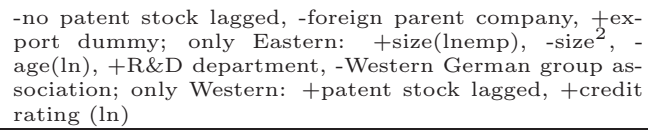 \\
\hline
\end{tabular}




\section{Stylized Facts of the German DPF scheme}

Information on the Federal government's DPF scheme is collected in a separate database called PROFI. This database encompasses detailed information on all projects funded under the DPF scheme, including starting and end dates of the funded projects, amount of public funding, total project costs, and all names of firms and public research organizations involved in the project. The database serves as basis for the description of the DPF scheme. Public financing of R\&D projects by the way of contract research is excluded from the data set.

Regarding the overall trend in the DPF scheme in the last 25 years, the number of projects and firms funded each year has changed considerably. In the early 1980 s, on average about 2,600 projects of about 1,000 different private firms were funded every year with more than 900 million euros of public funding per year. By the year 2005 the number of projects increased by a factor of about 1.6 and the number of involved firms by a factor of 2.5. The amount of the public subsidies decreased by 50 percent in the same period. Hence, the number of subsidized projects per firm as well as the average subsidies per project decreased over time. The distribution of subsidized projects per firm and year is shown in the left bar chart of figure 1. Two-third of the participating firms had one subsidized project in 1980. This share increased to 77 percent in 2000 and declined to 75 percent in 2005. This shift is mainly due to the fact that fewer firms have more than five projects subsidized in the last years. Therefore the projects were allocated less concentrated and more firms participated.

Figure 1: Distribution of subsidized and starting subsidized projects per firm and year within the DPF funding scheme, for different years
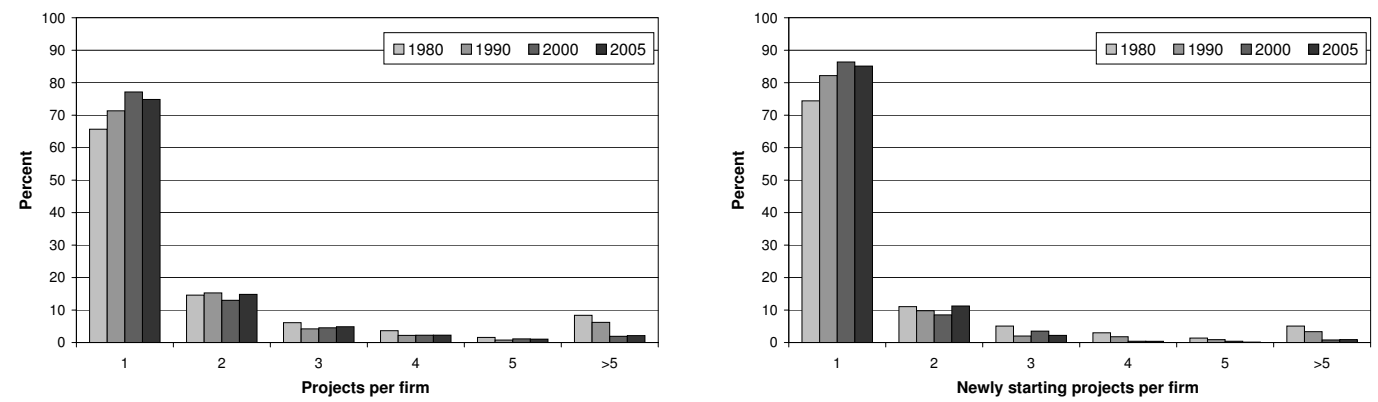

Source: PROFI database; own calculations. 
Since a project is subsidized on average for about three years, one third of the projects to be observed for a particular year have begun this year. In 1980 there were almost 800 starting projects which were carried out by about 400 different firms (see figure 2). ${ }^{8}$ The number of firms with new projects remained the same until 1992 and then began to increase. The peak in 2001 is due to the temporarily expanded budget for the DPF scheme. This was financed by the savings from the interest from the appropriation of the revenues of the auction of the UMTS licenses for public debt repayment. The number of new projects and firms involved therein have developed similarly to the overall trend. In recent years around 1,000 new projects in about 800 different firms were subsidized. Consequently, a lot more firms receive subsidies but each firm has fewer subsidized projects on average and the average award amount also decreased. The inclusion of more firms in the DPF scheme via the newly allocated projects can also be seen in the right diagram of figure 1 where the starting projects per firm are presented for four different points of time. Whereas in 1980, 74 percent of the firms with new projects got one newly subsidized projects and 5 percent got more than five new projects subsidized, the new projects were more broadly distributed in 2005 since 85 percent of the firms which have starting projects get funding only for one new project.

Since the main interest is the participation pattern in the funding scheme over time, in the next step I decompose the number of firms with new subsidized projects in a year in terms of their participation history. A look at the firms' funding history reveals that in the early 1980s 30 to 40 percent of the participating businesses received subsidies for the first time. ${ }^{9}$ As new technology areas were emphasized and funding was increasingly directed towards SMEs, the share of first time participants increased in the 1990s to 50 to 60 percent and remained at that level, although in the meantime the total number of firms that have participated in the DPF scheme at least once has increased substantially. From 2003 on - with the decrease of the number of starting projects - the share of first-time subsidized firms fell back to about 40 percent. In 2005 almost 50 percent of firms with starting projects also received subsidies in the previous year.

\footnotetext{
${ }^{8}$ The classification of firms whether they are subsidized or not is based on the announced period of the project. For example, when a project runs from August 2002 until March 2004, the firm is marked as being subsidized from 2002 to 2004. This does not necessarily correspond exactly to the years when the firm receives the payments. Since often the last payment is made in the year or the second year after the expiration of the project, the calculated transition rates are not biased due to delayed payments.

${ }^{9}$ Since the PROFI database begins in 1973 , it is not possible to control for subsidies given before that year. This data restriction might result in a slight shift from the group of firms which were funded before six or more years to the first time funded firms where the firms were subsidized before 1973. But this bias is assumed to be rather small and therefore negligible since the share of firms which re-enter the program after nine years is fairly low.
} 
Figure 2: Number of firms with new projects subsidized in the DPF scheme, controlling for the period since the firm was last subsidized (in years), 1980-2005

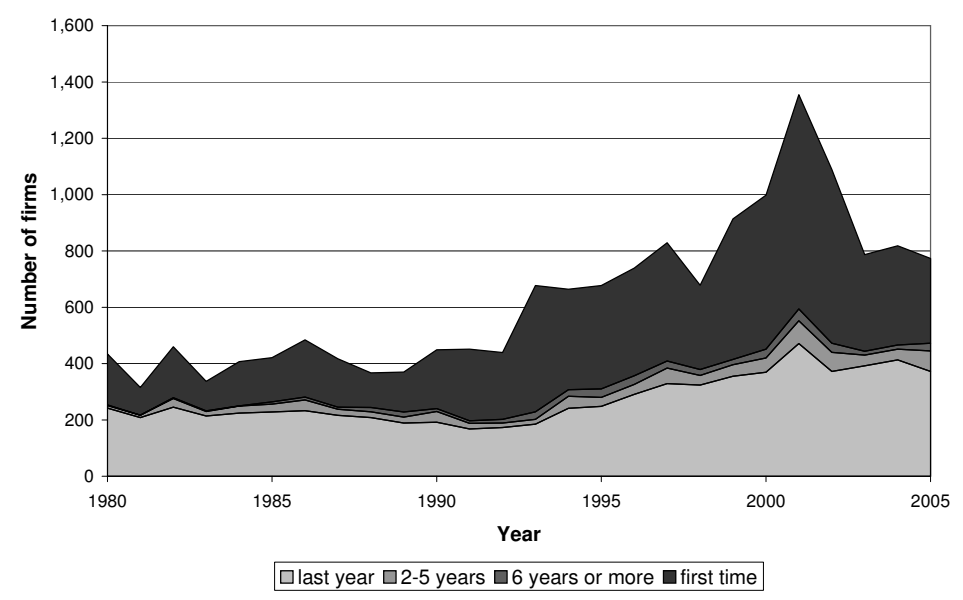

Notes: Last year: Firm had a subsidized project last year; 2-5 years: Firm had subsidized projects between 2 and 5 years ago; 6 years or more: Firm had a subsidized project 6 or more years ago; first time: Firm participates in the DPF scheme for the first time.

Source: PROFI database; own calculations.

The share of firms which receive subsidies occasionally is rather low as it is shown by the share of firms that were last funded between 2 and more years ago. This indicates that once a firm exits the program and does not receive subsidies anymore, it is not very probable that the firm will re-enter the program.

From the perspective of the DPF scheme - by looking at all participating firms - some dynamic is detected within the scheme since almost two-thirds of the firms which get new projects in a ten year period get new projects only in one year and about 40 percent of firms which get starting projects in a specific year participate for the first time. In order to assess the participation pattern further it is necessary to relate these subsidized firms to all firms, i.e. the population of firms. The PROFI database only includes participating firms since it is based on information on the subsidized projects. Therefore, I use a representative sample of the population of firms. This sample consists of both participants of the DPF scheme and non-participating firms which might be potential applicants. 


\section{Data Set and Some Statistics}

This analysis is intended to examine the program participation structure in Germany in a dynamic context and now looking at all firms. The sample used is based on the Mannheim Innovation Panel (MIP), an annual innovation survey conducted by the Centre for European Economic Research (ZEW) on behalf of the BMBF since 1993. The MIP is the German part of the European-wide harmonized Community Innovation Survey (CIS). It is a stratified random sample of firms according to firm size, industry and region. I pool the observations from all years to one dataset. I merge this firm level data with subsidy data which is extracted from the PROFI database. An advantage of this PROFI data set is that in contrast to other studies it contains information on subsidies on project-level. Thus the exact duration of the projects is known and it is possible to identify the years in which firms have newly granted projects or whether projects are just continued. ${ }^{10}$ The project-level data about the subsidies is aggregated to the firm-level because the analysis is carried out on the firm-level. The firm's subsidy status it known for every year since the subsidy information is extracted from another database which covers all years. Thus it is not necessary to observe the firm in two consecutive years in order to calculate transition rates for the subsidy status from one year to another.

Basically the programs within the DPF scheme are open to all firms. But naturally the DPF scheme is only interesting for firms if a program is placed within the industry in which the firm is active. Thus we restrict the sample to firms from the manufacturing sector and selected knowledge intensive services since the DPF scheme mainly targets these branches. ${ }^{11}$ Furthermore, I keep only observations for which all variables needed in the multivariate analysis are given. ${ }^{12}$ In the end, the sample consists of 6,360 different firms covering the manufacturing sector from 1994 to 2004 and the knowledge intensive service sectors since 1996.

In addition, it can be presumed that $R \& D$ subsidies are more relevant for firms which seek for innovations. Therefore I mark the firms which are engaged in innovative activities, i.e. their innovative expenditures are positive in $t$. Almost 5,000 of these firms have innovative activities.

Since the answering of the survey is not obligatory for firms the observed firms change from year to year in the dataset. How often the firms are observed is shown in table 2. Almost half of the firms of the whole sample are only ob-

\footnotetext{
${ }^{10}$ The classification of firms according to whether they are subsidized or not is based on the announced period of the project.

${ }^{11}$ See table 8 in the appendix for an overview of the included sectors.

${ }^{12}$ In addition, firms with more than 10,000 employees are dropped since for these firms the assignment of the subsidies is fairly difficult.
} 
served once. About 14 percent of the firms participate in two years or in three years. 62 firms and 19 innovating firms even participate in all 11 years. Overall, the sample consists of 16,958 observations, of which 11,252 are from firms with innovating activities.

Table 2: Firms' Observation Pattern in the Sample

\begin{tabular}{crrrrrrr}
\hline \hline \multirow{2}{*}{$\begin{array}{c}\text { No. of } \\
\text { observations }\end{array}$} & \multicolumn{3}{c}{ Whole sample } & & \multicolumn{3}{c}{ Innovating firms } \\
\cline { 2 - 3 } \cline { 6 - 8 } \cline { 6 - 7 } & No. of firms & Percent & No. of obs. & & No. of firms & Percent & No. of obs. \\
\hline & 3,040 & 47.80 & 3,040 & & 2,483 & 51.45 & 2,483 \\
3 & 892 & 14.03 & 1,784 & & 795 & 16.47 & 1,590 \\
4 & 903 & 14.20 & 2,709 & & 641 & 13.28 & 1,923 \\
5 & 361 & 5.68 & 1,444 & & 266 & 5.51 & 1,064 \\
6 & 372 & 5.85 & 1,860 & & 230 & 4.77 & 1,150 \\
7 & 196 & 3.08 & 1,176 & & 138 & 2.86 & 828 \\
8 & 238 & 3.74 & 1,666 & & 122 & 2.53 & 854 \\
9 & 122 & 1.92 & 976 & & 64 & 1.33 & 512 \\
10 & 119 & 1.87 & 1,071 & & 41 & 0.85 & 369 \\
11 & 55 & 0.86 & 550 & & 27 & 0.56 & 270 \\
Total & 62 & 0.97 & 682 & & 19 & 0.39 & 209 \\
\hline \hline
\end{tabular}

Note: ${ }^{a}$ Innovating firms are firms with positive innovation expenditures in $t$.

The sample includes firms which participated in the DPF scheme and firms which did not participate. The share of firms which received funding in the DPF scheme is shown in figure 3. Firms with positive innovation expenditures serve as a basis for calculating the share of subsidized firms. In the manufacturing sector the share of firms which participated in the funding scheme remained around eight percent from 1994 till 2000. Between 2001 and 2003 it increased to 13 percent and then it decreased again to its initial level. For the firms in the knowledge intensive service sectors basically the same pattern can be observed but at a three percentage points lower level on average. The overall slight increase of subsidized firms between 2001 and 2003 can be explained by the overall increase of firms participating in the funding scheme in this period as shown in section 4 .

A certain share of firms participate every year in the DPF scheme. However, the graph does not exhibit whether the same firms receive subsidies over time or whether and to which extent firms enter and exit the subsidy scheme. In order to analyze this question, the transition rates between being subsidized and being not subsidized are calculated and presented in table 3. Considering the whole sample it becomes apparent that the subsidization status is fairly permanent. Almost 99 percent of the firms which do not participate in the funding scheme in 
Figure 3: Share of innovating firms which receive DPF funding, 1994-2005

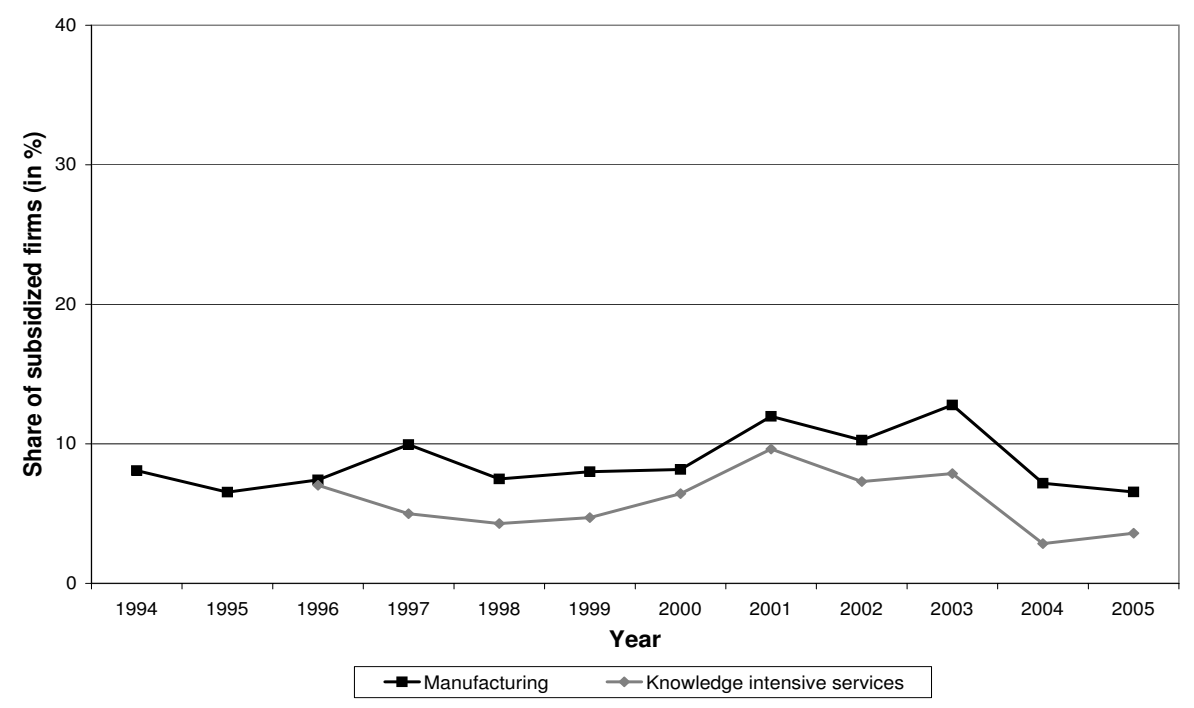

Notes: Innovating firms are firms with positive innovation expenditures. Contract research is not taken into account.

Source: Own calculations.

year $t$, do not receive this type of funding in the following year. Thus the share of firms which enter the funding scheme is extremely low. Looking at the yearly transition rates no upward or downward trend can be observed. ${ }^{13}$ Considering the non-subsidized firms in $t$ which also had no innovation activities in that period, the probability that they start to innovate by means of conducting $R \& D$ in $t+1$ and receive subsidies is below 0.3 percent. Virtually all of the newly subsidized firms in $t+1$ are firms which had already undertaken some type of innovation activities in $t$, and almost always $\mathrm{R} \& \mathrm{D}$ activities were conducted. Thus, it can be concluded that the funding scheme is not a method of stimulating firms to undertake R\&D activities. But this is also not the goal of this support scheme.

The status of the subsidized firms is persistent to a large extent. Over 80 percent of the subsidized firms maintained their status in the following period while almost 20 percent did not receive further funding and dropped out of the funding scheme. ${ }^{14}$ Compared to the results of the study conducted by Duguet

\footnotetext{
${ }^{13}$ Table of yearly transition rates for the not subsidized firms in $t$ can be found in table 9 in the appendix.

${ }^{14}$ Taking into account that in 2000 and since 2002 some firms which had received subsidies were added to the sample, the number of firms which are funded in $t$ is higher than otherwise, but the inclusion of these observations does not have a severe effect on the transition rates. For example, the transition rate of firms which remain subsidized from $t$ to $t+1$ even slightly
} 
Table 3: Transition Rates

\begin{tabular}{lccrc}
\hline \hline & & \multicolumn{3}{c}{ Status in $t+1$} \\
\cline { 3 - 5 } Status in $t$ & No. of obs. & Not subs. & Subs. & Total \\
\hline & & & & \\
Whole sample & & & & \\
Not subsidized & 15,635 & 98.80 & 1.20 & 100.0 \\
Subsidized & 1,323 & 17.61 & 82.39 & 100.0 \\
\hline Total & 16,958 & 92.47 & 7.53 & 100.0 \\
\hline & & & & \\
Sub-sample of innovating firms & & & \\
Not subsidized & 9,929 & 98.27 & 1.73 & 100.0 \\
Subsidized & 1,323 & 17.61 & 82.39 & 100.0 \\
\hline Total & 11,252 & 88.78 & 11.22 & 100.0 \\
\hline \hline
\end{tabular}

Note: ${ }^{a}$ Innovating firms are firms with positive innovation expenditures in $t$.

(2004) which considers R\&D subsidies from any national ministries in France, a slightly higher dynamic can be observed in France. Recalculating the given percentages in his study, it turns out that, for example, 7.5 percent of the firms without subsidies in 1996 receive subsidies in the following year. Given that a firm is subsidized in 1996, 75.6 percent of these firms also got subsidies in 1997.

However, it has to be considered that, once approved, projects in the DPF scheme last for several years, about three years on average. Continuation rates will be overestimated if the persistence due to multi-year projects is not taken into account. Therefore, in table 4 the subsidized status is split in $t+1$. A distinction is made between firms which have newly subsidized projects - and maybe additionally ongoing funded projects - and firms which have only ongoing subsidized projects. ${ }^{15}$ Decomposing the transition rate of firms which receive subsidies in both periods $t$ and $t+1(82.4 \%)$, it turns out that slightly above 20 percent of the subsidized firms in $t$ start actual newly subsidized projects in $t+1$. About 60 percent of the subsidized firms also receive subsidies in $t+1$ due to the fact that projects are approved for several years. Thus, the probability for firms to receive further funding in a new project is five percentage points higher than the probability of dropping out of the scheme (22.2\% vs. 17,6\%). The results show

increases from 82 to 85 for the sample when the extra firms were dropped. To check the representativeness of the sample, table 10 in the appendix compares the transition rates for the subsidized firms in $t$ of the population and the sample in each year. It turns out, that the firms with continued subsidies are slightly over-represented in the sample. But the bias is rather small.

${ }^{15}$ For period $t$ I consider two types, subsidized and non-subsidized firms. All of the subsidized firms in $t$ have a newly approved and subsidized project within the last four years. 
that once a firm has made it into the DPF scheme which is rather rare event, the probability of getting subsidies for new projects in the following year is more likely than dropping out of the scheme.

Table 4: More Detailed Transition Rates of Innovating Firms ${ }^{a}$

\begin{tabular}{lrrrrr}
\hline \hline & & \multicolumn{3}{c}{ Status in $t+1$} \\
\cline { 3 - 6 } & & $\begin{array}{r}\text { Not } \\
\text { Status in } t\end{array}$ & Nontinued & $\begin{array}{r}\text { Newly } \\
\text { No. of obs. }\end{array}$ & subsidized \\
subsidized & subsidized & Total \\
\hline Not subsidized & 9,929 & 98.27 & 0.00 & 1.73 & 100.0 \\
Subsidized & 1,323 & 17.61 & 60.17 & 22.22 & 100.0 \\
\hline Total & 11,252 & 88.78 & 7.07 & 4.14 & 100.0 \\
\hline \hline
\end{tabular}

Notes: ${ }^{a}$ Innovating firms are firms with positive innovation expenditures in $t$. Firms which have newly subsidized projects may additionally have ongoing subsidized projects.

Table 5 gives some more information on the dynamic of subsidization for innovating firms by their sector, location and size class. Looking at the firms' sector, the share of firms which enter the scheme in the manufacturing sector is about twice as high as in the service sector. This is not surprising since R\&D activities are more frequently undertaken in manufacturing firms. Differences in the transition rates for subsidized firms between the industry and service sectors are rather small. Regarding firms' location, the probability of entering into the funding scheme and dropping out of the scheme is the same for firms located in West and East Germany. But subsidized firms which are located in the Eastern part are more likely to get further funding within new approved projects than just having ongoing subsidized projects. Furthermore, the program participation transition rates vary with firm size. While 0.7 percent of the non-subsidized firms with less than 50 employees receive funding in the subsequent period, this share rises to 3.8 percent for firms with 250 employees or more. Regarding the subsidized firms in $t$, the rate of dropping out of the scheme is for the group of large firms lower by over six percentage points compared to the smallest firms. Thus both the probability of switching into the subsidization status and that of staying in this status increases with firm size. Therefore, the overall share of subsidized firms is higher for large firms than for small ones. As the next step, I want to identify firm-specific factors which influence these probabilities of entering and remaining in the DPF scheme. 
Table 5: Transition Rates of Innovating Firms ${ }^{a}$ by Firms' Sector, Location and Size Class

\begin{tabular}{|c|c|c|c|c|c|c|c|c|}
\hline \multicolumn{2}{|l|}{ Status } & \multicolumn{2}{|c|}{ Sector } & \multicolumn{2}{|c|}{ Location } & \multicolumn{3}{|c|}{ Size Class } \\
\hline Year $t$ & Year $t+1$ & Manu. & Service & West & East & $<50$ & $50-249$ & $>=250$ \\
\hline \multirow[t]{4}{*}{ Not Subs. } & Not subs. & 98.08 & 99.01 & 98.24 & 98.32 & 99.33 & 98.40 & 96.18 \\
\hline & Cont. subs. & 0.00 & 0.00 & 0.00 & 0.00 & 0.00 & 0.00 & 0.00 \\
\hline & Newly subs. & 1.92 & 0.99 & 1.76 & 1.68 & 0.67 & 1.60 & 3.82 \\
\hline & Total & 100.00 & 100.00 & 100.00 & 100.00 & 100.00 & 100.00 & 100.00 \\
\hline \multirow[t]{4}{*}{ Subs. } & Not subs. & 17.30 & 18.67 & 17.28 & 18.29 & 20.44 & 18.27 & 14.79 \\
\hline & Cont. subs. & 60.02 & 60.67 & 63.41 & 53.47 & 59.61 & 59.51 & 61.14 \\
\hline & Newly subs. & 22.68 & 20.67 & 19.30 & 28.24 & 19.95 & 22.22 & 24.06 \\
\hline & Total & 100.00 & 100.00 & 100.00 & 100.00 & 100.00 & 100.00 & 100.00 \\
\hline No. of obs. & & 8,938 & 2,314 & 7,494 & 3,758 & 4,579 & 3,834 & 2,839 \\
\hline
\end{tabular}

Notes: ${ }^{a}$ Innovating firms are firms with positive innovation expenditures in $t$. Firms which have newly subsidized projects may additionally have ongoing subsidized projects.

\section{Econometric Analysis}

\section{Econometric Model}

In this section the dynamics of firms' participation in the German DPF scheme are investigated in a multivariate context. It concentrates on the probability of a transition from one state of subsidization to another in the next period. In particular I focus on entry into the scheme and getting new projects approved if already in the scheme. In order to estimate these transitions I use the approach of markov chains which is seen as a powerful instrument for analyzing dynamic economic phenomena. (e.g. Nguyen Van, Laisney and Kaiser, 2004) I use a model based on Gouriéroux (2000) and applied by, for example, Nguyen Van et al. (2004) in the context of transitions between different states of firm performance or Fryges (2007) who analyzed changes between sales modes used by firms in international markets.

Let $Y_{i t}$ denote the status of subsidization $j$ of firm $i$ in time $t$ and takes value 1 if firm $i$ has a newly approved project in $t$ and value 0 otherwise. Assuming a logistic form for the transition probabilities and a set of explanatory variables $x$, the probability of transition of firm $i$ from state $j$ in $t$ to state $j^{\prime}$ in $t+1$ is given 
by

$$
P_{i j j^{\prime}}(t+1) \equiv P\left(Y_{i t+1}=j^{\prime} \mid Y_{i t}=j\right)=\frac{\exp \left(x_{i t+1} \beta_{j j^{\prime}}\right)}{\sum_{j^{\prime}=0}^{1} \exp \left(x_{i t+1} \beta_{j j^{\prime}}\right)},
$$

$i=1, \ldots, N, t=0, \ldots, T$, and $j, j^{\prime}=0,1$. For identification we impose the restriction $\beta_{j 0}=0$ and obtain

$$
\begin{aligned}
& P_{i j 0}(t+1)=\frac{1}{1+\exp \left(x_{i t+1} \beta_{j 1}\right)}, \\
& P_{i j 1}(t+1)=\frac{\exp \left(x_{i t+1} \beta_{j 1}\right)}{1+\exp \left(x_{i t+1} \beta_{j 1}\right)},
\end{aligned}
$$

with $j=0,1$. Consequently, each row of a transition matrix can be estimated by a binary logit model, assuming two possible states in $t+1$. Let us define $n_{i, t, t+1}\left(j j^{\prime}\right)=1$ if firm $i$ occupies status $j$ in $t$ and status $j^{\prime}$ in $t+1$, and 0 otherwise. Then the log-likelihood conditional on the state occupied at time $t$ is

$$
\ln L=\sum_{j=0}^{1} \sum_{j^{\prime}=0}^{1} \ln L_{j j^{\prime}}, \quad \text { with } \quad \ln L_{j j^{\prime}}=\sum_{i=1}^{N} \sum_{t=0}^{T} n_{i, t, t+1}\left(j j^{\prime}\right) \ln P_{i j j^{\prime}}(t+1) .
$$

Because the quantity $\sum_{j^{\prime}=0}^{1} \ln L_{j j^{\prime}}$ only depends on $\beta_{j 1}$, the maximum likelihood estimator $\hat{\beta}_{j 1}$ can be obtained by separate maximization of the elements of $\sum_{j^{\prime}=0}^{1} \ln L_{j j^{\prime}}$, where $j=0,1$.

By applying logit models it is possible to identify firm-specific factors which influence the probability of switching the subsidy status between two periods. I apply a logit type model that firstly explains the transition from the nonsubsidized status in $t$ to being subsidized in $t+1$, i.e. subsidy program entry. The share of firms which change their status, i.e. enter the scheme, is rather small compared to the event of remaining non-subsidized. King and Zeng (2001) show that the maximum likelihood estimator $\hat{\beta}$ is biased in rare events data in finite samples because the probability of the rare event is underestimated - in this case the estimated probability $\hat{P}_{i 01}$. They introduce a bias-correcting estimator $\tilde{\beta}$ and derive an analytical approximation for estimating the probability $P_{i 01}$ as

$$
P_{i 01} \approx \frac{1}{1+\exp \left(x_{i} \tilde{\beta}_{01}\right)}+C_{i}=\tilde{P}_{i 01}+C_{i}
$$

where the correction factor $C_{i}$ is

$$
C_{i}=\left(0.5-\tilde{P}_{i 01}\right) \tilde{P}_{i 01}\left(1-\tilde{P}_{i 01}\right) x_{i} \operatorname{Var}\left(\tilde{\beta}_{01}\right) x_{i}{ }^{\prime} \cdot{ }^{16}
$$

\footnotetext{
${ }^{16}$ For simplicity, I have neglected the time subscript $t$ in this formula.
} 
The estimator $\tilde{P}_{i 01}+C_{i}$, which is denoted as an approximate Bayesian estimator, is less biased - even though not unbiased - but it is superior in the sense that it has a smaller mean square error than other estimators of $P_{i 11}$. (King and Zeng, 2001) Thus, I apply this rare event logit model to estimate the first element of the log-likelihood function in equation (4), i.e. the entry into the DPF program.

Secondly, the transition from participating in the subsidy scheme in $t$ to getting another project subsidized in $t+1$ - renewing the subsidization status - is examined by means of a conventional logit model. If a firm get subsidies for a newly approved project in $t+1$, the dependent variable equals one. If a firm takes on value 0 for the dependent variable in $t+1$, the firm does not necessarily exit the subsidization status completely because firms might get further subsidies for previously approved projects. But it implies that the firm does not receive a grant for a new project in $t+1$. Thus the two states of being not subsidized at all in $t+1$ and having ongoing subsidized projects in $t+1$ that have been awarded in $t$ or previously, are combined. In these two states 'nothing' really happens to the firm.

I assume that the participation pattern follows a first-order Markov process, i.e. the state in $t+1$ only depends on the state of the previous period $t$. A Markov-chain of higher order is not necessary because the status of $t$ includes both newly and continually subsidized firms. Therefore, a large share are also subsidized in the prior period $t-1$ or before, due to the average duration of approved projects. Instead, I use an additional exogenous variable which accounts for the overall experience with the funding scheme: The number of projects that were granted within the last five years (between $t-4$ and $t$ ). This ensures that each earlier funded project is counted only once.

An alternative model to analyze persistence could be a dynamic panel discrete choice model. But due to the limited number of observations in specific and consecutive years and the few status changes between the years, this cannot be applied. Instead, I pool the data from the different years.

\section{Econometric Implementation}

The selection of variables used to explain the participation of firms in the DPF scheme is based primarily on the hypotheses described in section 2 and on the results of previous empirical studies (see section 3). The means of the explanatory variables are presented in table 6 , with separate values shown for the four possible state combinations of the dependent variables. 


\section{Subsidy-related variables}

Previous experience with the DPF scheme is assumed to have a positive effect on the probability of entering the subsidy program, again. There are various reasons for this as it was explained in section 2. In a nutshell, first, these firms might have learning effects and know how to submit a successful application. For the application they can fall back on their experience and need less effort. Due to asymmetric information, not all eligible firms are aware of the program and apply. Therefore, the probability of receiving subsidies is higher for the firms which had contact with the program previously. Third, a firm may have specific characteristics which increase its probability of success or it belongs to a group of firms which enjoy priority by the program agency. Regarding the second question, more experienced firms might also be more likely to stay in the program than a firm which have less experience due to the first reason. In order to analyze whether the experience with this specific subsidy scheme has an effect beyond the status at time $t$ which is given, the variable Experience is generated. It contains the number of approved projects within the preceding five years, i.e. between $t-4$ and $t$. Counting the projects not only distinguishes between experience and no experience but also reveals how much experience the firm has gathered. Regarding the sample of non-subsidized firms in $t, 17$ percent of the firms which switch into the subsidy scheme had at least one subsidized project between $t-4$ and $t-1$. This share is only 2 percent for the firms which stay not subsidized in $t+1$. The maximum number of approved projects in this period for nonsubsidized firms in $t$ is fairly low with two projects. Regarding the firms which were subsidized in $t$, the most successful firm in terms of getting projects approved in the last five years has 21 beginning projects. The average Experience variable is also significantly higher for the firms which get further funding via a new project in $t+1$. These firms have, on average, 3.6 subsidized projects within the last five years, thus about twice as many as firms with no or no new projects in $t+1$.

It is also controlled for whether a firm still gets subsidies from ongoing projects in $t+1$ with means of the dummy variable Continuation. The question is whether the still ongoing contact with the program agency has an additional positive impact on the likelihood of receiving further projects. On the other hand, the variable indicates when it takes the value zero, i.e. the firm does not get a new project granted in $t+1$, that the firm will drop out of the scheme because it has no ongoing projects in $t+1$. Thus these firms might be especially eager to get a new project funded. 77 percent of the only previously subsidized firms have a further funded project while 90 percent of the firms which get a newly approved project also have other ongoing subsidized projects. 
Table 6: Comparison of Means of the Explanatory Variables

\begin{tabular}{|c|c|c|c|c|}
\hline \multirow{2}{*}{$\begin{array}{l}\text { Status in } t \\
\text { Status in } t+1\end{array}$} & \multicolumn{2}{|c|}{ Not subsidized } & \multicolumn{2}{|c|}{ Subsidized } \\
\hline & Not subs. & Subs. ${ }^{a}$ & Not newly subs. & Newly subs. \\
\hline Continuation $_{t+1}$ & 0.000 & 0.000 & 0.774 & $0.898^{* * *}$ \\
\hline Experience $_{\text {since } t-4}$ & 0.026 & $0.209^{* * *}$ & 1.683 & $3.554^{* * *}$ \\
\hline Exp_EU $\mathrm{E}_{\text {since } t-2}$ & 0.069 & $0.177^{* * *}$ & 0.248 & $0.417^{* * *}$ \\
\hline Exp_regional $_{\text {since } t-2}$ & 0.161 & $0.297^{* * *}$ & 0.323 & $0.486^{* * *}$ \\
\hline Sub_supply $t+1$ & 3.182 & $4.459 * * *$ & 4.176 & $4.925^{* * *}$ \\
\hline Log(Employees) & 4.250 & $5.439 * * *$ & 4.845 & $5.232^{* * *}$ \\
\hline Employees_change & 0.030 & 0.033 & 0.039 & $0.066^{* *}$ \\
\hline Log(Age) & 2.705 & 2.796 & 2.735 & 2.684 \\
\hline R\&D_no & 0.279 & $0.047^{* * *}$ & 0.000 & 0.000 \\
\hline R\&D_occ & 0.237 & $0.163^{* *}$ & 0.149 & $0.061^{* * *}$ \\
\hline R\&D_con & 0.484 & $0.791 * * *$ & 0.851 & $0.939 * * *$ \\
\hline Qualification & 0.209 & $0.249^{* *}$ & 0.338 & $0.379 * *$ \\
\hline Patent_stock_dev ${ }^{b}$ & 0.697 & $2.459 * * *$ & 2.991 & $4.880^{* *}$ \\
\hline Group_national & 0.335 & $0.419^{* *}$ & 0.410 & 0.446 \\
\hline Group_foreign & 0.094 & 0.105 & 0.131 & 0.129 \\
\hline East & 0.335 & 0.326 & 0.301 & $0.415^{* * *}$ \\
\hline No. of obs. & 9,757 & 172 & 1,029 & 294 \\
\hline
\end{tabular}

Notes: ${ }^{a}$ All firms which do not receive subsidies in $t$ and enter the program in $t+1$ are newly subsidized. ${ }^{b}$ Since the patent stock is not available for 2003 and 2004, the number of observations is smaller for this variable. $* * *(* * *)$ indicate that the means are significantly different on the level of $1 \%(5 \%, 10 \%)$ based on a t-Test. Unless otherwise specified, the explanatory variables refer to time $t$. Industry and time dummies are not shown.

I not only control for the experience with the funding scheme in prior years, but also for experience with other sources of subsidies. Therefore, dummy variables are included to indicate whether the firm participated in a European $\left(E x p_{-} E U\right)$ or a regional (Exp_regional) funding scheme within the preceding three year period $t-2$ to $t$. On the one hand, firms which participate in a broad range of funding programs probably know the subsidy system with its funding opportunities quite well and have a lot of expertise in applying for and getting public grants. On the other hand, the DPF scheme might particularly support firms which do not get other subsidies. However normally other subsidy sources are unknown to the agencies which decide on the projects, if they get these subsidies for other projects, than those they applied to DPF. Therefore, a positive effect of applying and granting is expected. The comparison of means shows that firms with new subsidized projects in $t+1$ also get subsidies from the two other sources of funding significantly more often than the other firms. For France and Spain, positive effects of previous subsidies on the likelihood of participation 
in any program were found, as is shown by Duguet (2004) using past subsidy dummy and past subsidy rate and González et al. (2005) with subsidy dummies lagged by one and two periods. None of the two studies controlled for whether the past subsidies were given in the same subsidy program. Focusing on a specific scheme Tanayama (2007) found a positive relation between the number of prior applications and filing a further application whereas Feldman and Kelley (2001) did not detect a significant effect.

In addition, the beginning of funding programs in new areas is controlled for. From time to time, the government launches sub-programs within the DPF scheme in 'new' technology areas or shifts the focus from one area of research to another. Firms from other industries might be addressed so that new firms are recorded - naturally - within the DPF scheme or the firms' chances of getting a subsidy increase due to the higher supply of subsidies. In contrast, in other technology areas where programs end, chances of getting a subsidy decrease. In order to take these shifts over time into account in the estimation, the variable Sub_supply is generated which includes the amount of subsidies (in 10 million euros) which are approved for starting projects within a certain industry ${ }^{17}$ in year $t+1$. This variable is constructed based on the PROFI database and represents the population of the DPF scheme. Thus it is a proxy for the supply of subsidies for a firm. Comparing the firms with newly subsidized projects and with no (new) projects, it becomes apparent that the supply of subsidies is larger in those branches and years for firms with approved projects. On an average, above 45 million euros are authorized for new projects in these industries per year. In the industries of not newly subsidized firms in $t+1$ the amounts are 32 million euros and 42 million euros, respectively. Wallsten (2000) constructed a variable in his study which approximates the SBIR budget potentially available to each firm, depending on the type of research. He found a positive effect of this variable on the probability of winning an SBIR Phase I and II award.

\section{Other variables}

As explained in section 2, firm size is expected to be an important variable in explaining the participation in the DPF program though the direction of the impact is ambiguous. A firm's size is measured by the number of employees in logarithms (Employees). The comparison of means exhibits that firms with new subsidized projects are significantly larger than those firms without (new) projects. Comparing the two groups with newly subsidized projects in $t+1$ and considering the average firm size with means of the number of employees (not in

\footnotetext{
${ }^{17}$ The programs within the DPF scheme are linked to technology areas which cannot be directly converted into industries, e.g., based on the NACE classification. However, in order to control for the supply, the industries which the participating firms belong to are taken into account. The classification of the industries can be found in the appendix in table 8 .
} 
logarithms), the firms which were already subsidized in $t$ are 1.5 times larger as the firms which just entered the program (917 vs. 582 employees). This indicates that only the largest firms regularly get subsidies for new projects and contradicts the aim of focussing on SMEs. The increase of the participating probability with firm size is found for most subsidy programs, e.g. Duguet (2004), González et al. (2005), Czarnitzki and Fier (2002), or Blanes and Busom (2004). The only study which found a negative effect of firm size is the one by Busom (2000).

Besides the level of the employees, the change in the number of employees between $t-1$ and $t$ relative to the number of employees in $t-1$ is also included in the regressions (Employees_change). It is assumed that firms which have developed positively and are already on a growth path may most likely be picked by the program agency in order to augment this development. Looking at the descriptive statistics, the average firm growth is not significantly larger for firms which enter the scheme than for the ongoing not subsidized firms. Hence it does not seem to be that growing firms are more likely to be picked. If the firm has been subsidized in the previous years, this growth can also be an effect of the public support. Indeed employment growth is significantly larger for the subsidized firms which get a new project granted.

Young firms should also enjoy special attention under Federal innovation policy. Young high-tech firms may suffer from a lack of financial capacity, due to insufficient resources of their own and limited access to capital markets. However, the DPF scheme does not focus on start-up firms in particular though there are some sub-programs which target high-tech start-ups, for example, BioChance in the biotechnology field. Whether age plays an actual role in receiving subsidies, is examined by the logarithm of a firm's age (in years, $\log ($ age $)$ ). The mean of firm's age does not exhibit a significant difference between the groups. The effect of age is not clear throughout the programs and countries. While González et al. (2005) and Busom (2000) found a positive impact of age, it has no effect in the studies of Czarnitzki and Fier (2002) and Almus and Czarnitzki (2003).

Overall, the sample is restricted to firms with positive innovation expenditures. However this does not necessarily imply that the firms actively conduct R\&D. Innovation expenditures also include expenditures for extramural R\&D (allocated to and performed by other companies), the acquisition of machinery, equipment, software or other external knowledge, training for firms' personnel specifically for the development and/or introduction of new or significantly improved products and processes etc. Since the DPF scheme is directed towards R\&D activities, the past performance of these activities indicates the experience with R\&D and accumulated knowledge in R\&D. Due to the activities in this area, firms with in-house R\&D might also be aware of potential support programs offered. Thus in-house R\&D activities probably enhance the probability 
of applying to the DPF scheme. The program agency might also favor firms with the capability to successfully carry out R\&D. Conducting of R\&D activities is distinguished according to the regularity of these activities. The variable $R \& D \_$occ $\left(R \& D \_c o n\right)$ indicates that the firm performs $R \& D$ on an occasional (continuous) basis. A proportion of the not subsidized firms in $t$ may also have no such activities $\left(R \& D \_n o\right)$. Continuous R\&D activities are significantly more often observed for newly subsidized firms. A significantly positive effect of the extent of R\&D activities was found in several studies, e.g. Czarnitzki and Fier (2002) which used the regularity of R\&D activities, Almus and Czarnitzki (2003) for the existence of an R\&D department, Czarnitzki et al. (2004) for the share of R\&D employees and Duguet (2004) for the ratio of private $R \& D$ expenditure to sales.

In addition to R\&D activities, another measure of firms' capabilities to generate and acquire knowledge is included in the regressions: The share of employees with a university degree (Qualification). Since qualified employees within the $R \& D$ process increase the human capital within $R \& D$ and the absorptive capacity, more ideas for future R\&D projects are generated. (Blanes and Busom, 2004) Hence, the pool of potential R\&D projects is larger and thus the probability of promising and profitable projects among them increases. Qualified employees in the administration area might be more successful in fund-raising for $R \& D$ projects. (Czarnitzki and Fier, 2002) Thus this variable is expected to have a positive effect on the likelihood of applying for a subsidy and being approved by the program agency. The descriptive statistics show that firms with new projects have a higher share of qualified personnel. The positive influence of human capital on the participation in subsidy schemes is shown by Blanes and Busom (2004) and Czarnitzki and Fier (2002).

A proxy variable for a firm's capacity to create new knowledge is its patent stock (Patent_stock). Firms have proved to be able to transfer R\&D into inventions, which is a main success criteria under the DPF scheme. This variable is generated by depreciating the sum of all patent applications which were filed at the European Patent Office since 1979 until $t$. The depreciation rate is constant and equals 0.15, which is common in the literature. (e.g. Hall, 1990) ${ }^{18}$ Since the patent behavior varies between industries, the variable used in the regressions is scaled to the industry mean and measures the deviation rate from the industry average (Patent_stock_dev). The firm's patent stock is divided by the average of the patent stock in the industry (2-digit-level). Since the patent information is only available up to the year 2002, the impact of this variable is analyzed by a

\footnotetext{
${ }^{18}$ The resulting formula for the calculation of the patent stock of firm $i$ at time $t$ is: Patent_stock $_{i t}=(1-D R) *$ Patent_stock $_{i t-1}+P A_{i t}$ where DR is the Depreciation Rate and PA the number of filed patent applications.
} 
sub-sample of firms which excludes the observations from 2003 and 2004. The descriptive statistics show that firms which have a higher patent stock compared to the industry average both enter into the scheme and renew their status with new grants more often.

Firms which belong to a company group might benefit from this membership due to knowledge transfers within the group. Besides, SMEs which belong to a group with a large parent company are not eligible anymore for DPF subprograms designed for SMEs. The DPF scheme might be also oriented in particular towards domestic firms since the government wants to generate economic effects located in Germany out of DPF funding. In order to control for this, two dummy variables are included in the regression. Group_national takes on the value one if the firm is part of domestic company group. If the firm has a foreign headquarter, group_foreign equals one. In the descriptive statistics no significant difference can be observed. A negative effect of a foreign parent company was found by Aerts and Czarnitzki (2004) for Belgium.

In Germany there is a special situation due the country's history and the reunification in 1989. The Eastern part is still way behind in terms of productivity, and large transfer payments and promotion programs are directed to this geographic region. But the DPF scheme is not part of this system and does not focus particularly on firms located in the Eastern part, except the two sub-programs InnoRegio and Innovative Regional Growth Cores. However, due to still existing differences between the Western and Eastern part, I include a dummy variable (East) for firms located in Eastern Germany in the regressions. Regarding entering into the scheme, there is no systematic difference. But once firms have entered the scheme and are subsidized, firms from the Eastern part are more likely to receive subsidies for new projects.

To capture additional industry specific effects, dummy variables are included in the regressions, indicating to which sector a firm belongs to. The sectors are defined based on the technology-level and according to the OECD taxonomy. (OECD, 2003) About 63 percent of the firms with newly approved projects in $t+1$ are from the medium-high or high technology manufacturing sector. In addition, year dummies are generated in order to control for temporal heterogeneity.

To identify the determinants for continuous subsidization under the DPF by newly approved projects, basically the same variables are used as for the explaining of entering into the DPF scheme. In order to get further projects approved it can be assumed that firms had to prove themselves in the previous subsidized projects. But variables indicating the success of former subsidized projects are not available and so cannot be taken into account. Instead, firm variables are included in order to detect which characteristics these firms have. It is also possible 
that receiving DPF funding over a long time may have changed firm characteristics. Comparing the firms which do not receive subsidies in $t$ and enter the program in $t+1$ with the firms which received subsidies in $t$ and also have newly granted subsidies in $t+1$, it becomes apparent that in fact most explanatory variables differ.

\section{Empirical Results}

The results of the regressions are presented in table $7 .^{19}$ The first column includes the vector of coefficients which explain the transition from the status non-participant at time $t$ to the status participant at time $t+1$, i.e. entry into the DPF scheme. ${ }^{20}$ The third column shows the coefficients which discriminate between firms that have a newly approved project in $t+1$ and those which do not, for subsidized firms in $t$. In columns two and four the respective marginal changes, calculated as first differences, are shown.

\section{Subsidy-related variables}

The results show that prior experience with the funding schemes (Experience), measured as the number of approved projects within the last five years, helps firms to enter the program again, compared to firms which did not participate in the program before. The more experience a firm has with the funding scheme, the higher is the probability of getting new projects approved in $t+1$ provided that the firm is subsidized already at time $t$. The relationship between experience and the predicted probability of getting a new project funded for subsidized firms in the preceding period is depicted by the lower right graph in figure 4 in the appendix. Setting all other variables to their mean, the graph clearly reflects the positive correlation between the number of employees and the (predicted) propensity to get a new project approved. The large impact of firm's experience can also be seen by the predicted probability reached by this variable. ${ }^{21}$

The continuation of a subsidized project (Continuation), i.e. getting subsidies in $t+1$ for a project which was approved some time before, has no effect

\footnotetext{
${ }^{19}$ The results were obtained using the statistical software package STATA, version 9.2 SE. For the estimations of the rare events logit model, I used a program written by Michael Tomz, Gary King, and Langche Zeng, which is available at http://gking.harvard.edu. (King and Zeng, 2001)

${ }^{20}$ Applying a conventional logit model, the coefficients increase or decrease slightly and the standard errors are slightly larger. However, the category of the significance level of the variables remains the same.

${ }^{21}$ One might think that firms which conduct the subsidized projects in a co-operation with other firms or research institutions have a higher probability of getting new projects approved since the support of joint projects become more important. Since $90 \%$ of all firms with subsidized projects in $t$ are involved in joint projects, including a corresponding dummy variable in the regression, this does not have a significant effect.
} 
Table 7: Regression Results

\begin{tabular}{|c|c|c|c|c|}
\hline \multirow[b]{2}{*}{ Variable } & \multicolumn{2}{|c|}{$\begin{array}{l}\text { Not Subsidized } \rightarrow \text { Subsidized } \\
\text { Rare events logit model }\end{array}$} & \multicolumn{2}{|c|}{$\begin{array}{c}\text { Subsidized } \rightarrow \text { Newly Subsidized } \\
\text { Logit model }\end{array}$} \\
\hline & $\begin{array}{l}\text { Coefficient } \\
\text { (Std. Err.) }\end{array}$ & FD & $\begin{array}{l}\text { Coefficient } \\
\text { (Std. Err.) }\end{array}$ & $\mathrm{FD}$ \\
\hline Continuation $_{t+1}$ & & & $\begin{array}{r}0.354 \\
(0.224)\end{array}$ & 0.0506 \\
\hline Experience $_{\text {since } t-4}$ & $\begin{array}{l}1.236^{* * *} \\
(0.198)\end{array}$ & 0.0214 & $\begin{array}{l}0.363^{* * *} \\
(0.051)\end{array}$ & 0.0483 \\
\hline Exp_EU ${ }_{\text {since }} t-2$ & $\begin{array}{l}0.525^{* *} \\
(0.241)\end{array}$ & 0.0059 & $\begin{array}{c}0.287^{*} \\
(0.170)\end{array}$ & 0.0439 \\
\hline Exp_regional $_{\text {since } t-2}$ & $\begin{array}{l}0.462^{* *} \\
(0.227)\end{array}$ & 0.0050 & $\begin{array}{r}0.206 \\
(0.175)\end{array}$ & 0.0316 \\
\hline Sub_supply $_{t+1}$ & $\begin{array}{l}0.052^{* * *} \\
(0.018)\end{array}$ & 0.0002 & $\begin{array}{c}0.040^{*} \\
(0.022)\end{array}$ & 0.0027 \\
\hline Log(Employees) & $\begin{array}{l}0.535^{* * *} \\
(0.057)\end{array}$ & 0.0000 & $\begin{array}{l}0.155^{* *} \\
(0.065)\end{array}$ & 0.0012 \\
\hline Employees_change & $\begin{array}{r}0.125 \\
(0.272)\end{array}$ & 0.0001 & $\begin{array}{l}0.846^{* *} \\
(0.427)\end{array}$ & 0.0133 \\
\hline Log(Age) & $\begin{array}{r}-0.010 \\
(0.067)\end{array}$ & 0.0002 & $\begin{array}{r}0.013 \\
(0.077)\end{array}$ & 0.0002 \\
\hline R\&D_occ & $\begin{array}{l}1.089^{* * *} \\
(0.410)\end{array}$ & 0.0137 & & \\
\hline R\&D_con & $\begin{array}{l}1.394^{* * *} \\
(0.377)\end{array}$ & 0.0139 & $\begin{array}{c}0.512^{*} \\
(0.310)\end{array}$ & 0.0695 \\
\hline Qualification & $\begin{array}{l}1.143^{* * *} \\
(0.308)\end{array}$ & 0.0011 & $\begin{array}{l}0.715^{* *} \\
(0.346)\end{array}$ & 0.0112 \\
\hline Group_national & $\begin{array}{l}-0.312^{*} \\
(0.182)\end{array}$ & -0.0026 & $\begin{array}{r}0.011 \\
(0.185)\end{array}$ & 0.0017 \\
\hline Group_foreign & $\begin{array}{l}-0.707^{* *} \\
(0.293)\end{array}$ & -0.0050 & $\begin{array}{r}-0.193 \\
(0.272)\end{array}$ & -0.0282 \\
\hline East & $\begin{array}{r}0.126 \\
(0.203)\end{array}$ & 0.0013 & $\begin{array}{l}0.588^{* * *} \\
(0.192)\end{array}$ & 0.0958 \\
\hline Constant & $\begin{array}{l}-8.295^{* * *} \\
(0.492)\end{array}$ & & $\begin{array}{l}-4.372^{* * *} \\
(0.780)\end{array}$ & \\
\hline $\begin{array}{l}\text { No. of obs. } \\
\text { Wald } \chi_{\text {all }}^{2} \\
\text { Wald } \chi_{\text {year }}^{2} \\
\text { Log-Likelihood } \\
\text { Mc Fadden's } R^{2}\end{array}$ & $\begin{array}{c}9,929 \\
255.59^{* * *}\end{array}$ & & $\begin{array}{c}1,323 \\
140.84^{* * *} \\
20.98^{* *} \\
-585.588 \\
0.164\end{array}$ & \\
\hline
\end{tabular}

Notes: $* * *(* *, *)$ indicate significance level of $1 \%(5 \%, 10 \%) ; \mathrm{FD}=$ First Difference. The first difference gives the discrete change in the expected value caused by increasing dummy variables from 0 to 1 , Experience from 0 to 1 (1 to 2) in first (second) regression, the mean of Sub_supply, Employees and Age by 10 percent and the mean of Employees_change and Qualification by 10 percentage points, while holding the other explanatory variables at their means. Unless otherwise specified, the variables refer to time $t$. Standard errors are clustered by firm because almost $50 \%$ of the firms appear more than once in the sample. 
on remaining in the program. Thus the possibility that a firm drops out of the scheme does not increase the likelihood of getting a new project granted. This also indicates that subsidies are not necessarily approved after another project has ended. Instead firms may have several subsidized projects at the same time.

Experience with other innovation programs has a significant effect on the probability of entering the program. The effect of having participated in a EU program $\left(E x p_{-} E U\right)$ is slightly higher than participation in regional programs (Exp_regional). This might be due to the fact that the EU application process is more similar, and maybe closer in terms of what is demanded, to the DPF than regional programs are. However, successful applications to other programs is almost irrelevant for getting new projects approved once a firm is in the DPF scheme. Overall, experience with the specific subsidy scheme greatly helps to place another successful application. Experience with other subsidy programs has a favorable effect on entering the program but not on staying in it.

Besides the experience with subsidy programs, it is of course imperative that subsidies are offered to the particular industry in which a firm operates at the 'right' time (Sub_supply). This is particularly relevant to the DPF scheme which offers thematically focused $\mathrm{R} \& \mathrm{D}$ funding within predefined areas of technology. If the supply is large in the industry at time $t+1$, the probability of entering the program and receiving new subsidies increases. Thus in order to identify the pattern of participation, it is necessary to control for the overall supply of subsidies by sectors and years.

\section{Other variables}

The objective of the government to subsidize particularly SMEs in this scheme cannot be confirmed. The probability of non-subsidized firms in $t$ entering the scheme and the probability of subsidized firms in $t$ getting funding for a new project increases with firm size. ${ }^{22}$ The upper graphs in figure 4 depict the predicted probability for the two transitions dependent on the number of employees, with all other variables set to their mean. Since the program entry constitutes a rare event, the corresponding predicted probability is fairly low in absolute terms and only reached 0.3 percent for firms with less than 1,000 employees. But it is not negligible because of that. While the graph shows that the predicted probability of entering the scheme increases for all firm sizes in this range, the corresponding graph for the probability for already subsidized firms of getting a new project approved only has a relatively steep slope for smaller firms. The graph becomes more flat with more than 200 employees. Overall, the positive correlation between firm size and the propensity of getting a project approved

\footnotetext{
${ }^{22} \mathrm{I}$ also included the squared employee variable in the regression in order to control for a potential non-linear relationship. But the squared term was not significant in both regressions.
} 
can be seen. The source of this divergence from the government's objective cannot be detected. Either SMEs do not apply more frequently for subsidies, or the agency does not enforce this focus, or the focus is only set in very few programs within the DPF scheme so the effect does not show when all industries are taken into account. Bearing in mind that the sample covers the period 1994-2004, it is also possible that there was a shift towards SMEs over this period, but that this was not revealed due to the pooling of cross-sections. Firms' age (Age) does not matter since it does not have a significant effect on either transition probability.

A firm's employment growth in the past (Employees_change) does not have an effect on the probability of entering the scheme but positively influences the likelihood of getting further subsidies. The growth might be seen as an indicator of the successful conduct of previously subsidized projects. One has to bear in mind that all of these firms have received subsidies from DPF before.

In order to enter the DPF scheme, it is important that firms are engaged in R\&D. It is not sufficient to have innovation activities - the sample is restricted to firms with positive innovation expenditures - but in addition firms should undertake their own $R \& D$. The likelihood of entering the scheme increases if $R \& D$ activities are conducted. But it does not matter whether R\&D is conducted continuously or occasionally since both coefficients are statistically equal. On average the probability increases by one percent if a firm conducts its own R\&D. In those cases in which a firm receives subsidies from the DPF scheme in $t$, the firm conducts R\&D at least occasionally. Discriminating between the two levels, it is shown that continuous R\&D activities only slightly increase the likelihood of getting funding for a new project. ${ }^{23}$ Furthermore, human capital is relevant (Qualification). When a firm has a larger share of graduated employees, the probability of entering the program increases either because, for example, they apply more often, have better elaborated applications or are chosen more often by the agencies. The effect on the probability is larger for firms with higher shares of qualified employees as is displayed in the lower left graph in figure 4. These capabilities still affect the probability of getting new projects if the firm already participates in the scheme.

It is assumed that firms which already have a better technological performance - measured by firm's patent stock compared to the industry average (Patent_stock_dev) - might be picked by the program agencies because they are promising candidates. This is examined by means of a sub-sample of firms. Since the patent applications are not known for 2003 and 2004, observations from these two years were dropped. In table 11 in the appendix the results of the regressions

\footnotetext{
${ }^{23}$ I also included the innovation intensity as an explanatory variable, but no significant effect on the probabilities was detected.
} 
are shown. In columns (a) and (c) the same regressions as in table 7 are shown, but using the sub-sample. In the regressions presented in columns (b) and (d) the patent stock variable is included. It turns out that the patent stock does not have an effect on the probability of entering into the support scheme or renewing the status in the scheme. I also ran a regression with the firms' patent stock not related to the industries average, but the results remained the same. ${ }^{24}$ Thus former success with R\&D activities in terms of patent applications does not matter in this context.

Overall, differentiating between the two measures which either indicate that the firm is already technologically further developed than others (Patent_stock dev) or that the firm is on a promising and successful path because it grows (Employees_change), none of the variables have an impact on entering the scheme. It seems to be sufficient that a firm shows that it has the overall capabilities to finish the suggested project successfully. But the employment growth might be seen as a success indicator of previously subsidized projects because the higher the growth rate the higher is the likelihood of getting further projects granted.

The affiliation to a domestic company group (Group_national) and whether the headquarters are located abroad (Group_foreign) negatively affect the allocation process if a firm enters the program. The effect is more significant for firms with a foreign headquarter than a national one. Once a firm is in the scheme, the status of belonging to a company group has no further effect on getting new projects approved. For the probability of entering the funding scheme it does not matter where the firm is located (East), i.e. whether it is located in the Eastern or Western part of Germany. But once a firm from the Eastern part has made it into the scheme, it has a higher probability of getting further projects approved. As a consequence the East German firms' participation is relatively high in the scheme. This result is noteworthy since for East Germany a variety of other public support programs are available for firms in this area.

The industry, classified according to the technology scope, in which a firm operates does not seem to have a significant effect on the transition probabilities. Performing a Wald test, joint significance of the industry dummies could not be found in any regression and thus are dropped from the presented regressions. Industry effects obviously only relate to the supply-side effects of program volumes offered to a certain sector. The year dummies were only jointly significant in the second regression and therefore included in that regression. The overall low

\footnotetext{
${ }^{24}$ I also included in one regression the patent stock variable but excluded the variable Qualification since it might be suspected, that a potential effect of the patent stock is captured by the qualification variable, though the correlation between these two variables is low $(-0.02(-0.08)$ in the sample of not subsidized (subsidized) firms in $t$ ). Excluding the variable Qualification from the regression does not change the results.
} 
additional explanation power of these two sets of dummy variables may be due to the inclusion of the overall subsidy supply variable which is generated on a more detailed industry level and a yearly basis.

\section{Sensitivity tests}

In order to test the sensitivity of the results, I split the sample according to a firm's size or location and run the regressions for the sub-samples again. In order to conduct separate estimations depending on firm's size, I differentiate between small, medium and large firms. Firms with 50 employees or less are considered as small firms. Medium-sized firms have between 51 and 500 employees. Firms with more than 500 employees are deemed to be large firms. The results are presented in table 12 in the appendix. It becomes apparent that some factors differ with firm size regarding the entry into the subsidy scheme. In the group of small firms, young firms are more likely to enter the scheme. Participating experience in regional subsidy programs particularly helps medium-sized firms to get into the funding scheme. Large firms do not need to exhibit their knowledge capabilities. Neither the R\&D activities nor the share of qualified employees have an effect. I also split the sample into two sub groups, according to whether firms in the sample are located in the Western or Eastern part of Germany. About two-thirds of the firms are located in West Germany. There is one noticeable difference, i.e. experience in other funding schemes increase the probability of entering the scheme only for Western firms.

The analysis also shows that the results differ for the two transition probabilities, i.e. different variables have an effect on the receipt of a new subsidy, depending on whether the firm participated in the previous period. These differences indicate a different selection for the two groups, either on firms' application side or authorities' approving side, although there are no official rules to evaluate projects of already participating firms differently.

\section{Conclusions}

In this study the participation pattern of firms over time within the German $R \& D$ funding scheme, the DPF scheme, is analyzed. In order to investigate the persistence of funding it is necessary to distinguish between two types of persistence. One is simply due to the fact that funded projects may run for more than one calendar year. The other is due to newly approved projects. In the DPF scheme, approved projects last on average for about three years.

Looking at the firms which participate in the DPF scheme some dynamic is detected since about 40 percent of firms which get starting projects in a specific 
year participate for the first time. In a second step the DPF scheme is related to the population of firms by using a representative sample of German firms. Transition rates are calculated which describe the participation in a univariate context. The share of innovating firms which enter the funding scheme is extremely low. Over 98 percent of the firms which do not participate in the DPF scheme in a particular year, do not receive DPF funding in the following year. Thus the detected dynamic within the DPF scheme decreases if the new entrants are related to the population of firms.

The rate at which subsidized firms are also subsidized in the following year equals about 80 percent. Distinguishing between the two types of persistence, 22 percent of subsidized firms get new subsidized projects in the following year and 60 percent of the firms remain subsidized due previously approved projects. Thus, the subsidization of firms is quite persistent in the examined support scheme. Several reasons might be responsible for this finding. On the side of firms applying, it might be due to the existence of asymmetric information. Not yet subsidized firms may have information deficiencies regarding possible sources of funding. On the other hand the subsidized firms might have realized learning effects due to previous applications or participation in the scheme, with the result that they are selected more often. However the finding could also be due to the program agencies' selection rules and the result of a policy favoring a certain clientele. In this case the subsidy policy should be reconsidered. It cannot be distinguished whether the allocation pattern found is due to the application behavior of firms or due to the decision of the program agencies. We can only observe the net outcome: whether a firm is (newly) subsidized or not. It would definitely be a step forward if corresponding data were available for this support scheme from the firm's first contact with the program agency onwards.

The multivariate analysis shows that for the probability of getting new projects approved for the funding scheme, experience in the same scheme matters, beyond the subsidy status in the preceding year. At the same time, it is important to control for the overall supply of subsidies for different industries. In addition, large firms are more successful in receiving funding for new projects. Thus the evidence cannot confirm that the scheme is achieving the government's aim of supporting SMEs in particular. The hypotheses that firms with higher knowledge capabilities are more likely to enter and stay in the scheme can be supported as I found positive impacts of R\&D activities and human capital. Recent firm growth also increases the probability of receiving further grants in the following year if a firm participates. Thus, the most promising and best equipped firms participate more frequently in the DPF scheme which indicates a picking-the-winner strategy on the part of the program agency. On the other hand, the actual and achieved technological performance of a firm - measured by a firm's patent stock compared to the industry average - does not matter regarding the participation 
in the support scheme. Firms located in East Germany have a higher probability of remaining subsidized, once they make it into the scheme. The disproportionate participation of East German firms is noticeable since a variety of other public support programs exist solely for this area.

The differences in the regressions results indicate a different selection for the two groups - new DPF entrants and new projects for DPF participants-, either on firms' application side or on authorities' approving side. As argued earlier, the source of the difference cannot be identified. Another shortcoming in the data used in this study is that no variables regarding the success of prior subsidized projects are known. This project-level information might have an impact on the decision to approve another project of a subsidized firm.

This work is an investigation of the dynamics of an $R \& D$ funding scheme. It looked at which firms receive the public financial support and how this public support evolves over time. It tries to assess whether the participants correspond to the government's announcements of whom they aim to reach with the particular scheme. Besides no assessment of the effectiveness of the allocation of public money has been made. In this study the receipt of the money is a binary variable, either a firm participates or not. But it would also be worthwhile to consider the amount of money in order to weight the participation and assess its importance. In a further step the effects of public funding should be investigated so that the allocation can be evaluated. In doing so it would be important to distinguish between the different types of participants, i.e. whether a firm is new or regularly in the scheme. Another issue for further research would be to examine the behavior of the firms and therefore the program effects might change if a firm is continually publicly funded so that they count on the money. 


\section{References}

Adams, J. and Jaffe, A. (1996). Bounding the Effects of R\&D: An Investigation using matched Establishment-Firm Data, RAND Journal of Economics 27(4): 700-721.

Aerts, K. and Czarnitzki, D. (2004). Using Innovation Survey Data to Evaluate R\&D Policy: The Case of Belgium, Discussion Paper No. 04-55, Zentrum für Europäische Wirtschaftsforschung (ZEW).

Ali-Yrkkö, J. (2005). Impact of Public R\&D Financing on Private R\&D - Does Financial Constraint Matter?, Working Paper No. 30, European Network of Economic Policy Research Institutes (ENEPRI).

Almus, M. and Czarnitzki, D. (2003). The Effects of Public R\&D Subsidies on Firms' Innovation Activities: The Case of Eastern Germany, Journal of Business and Economic Statistics 21(2): 226-236.

Blanes, J. V. and Busom, I. (2004). Who participates in R\&D subsidy programs? The case of Spanish manufacturing firms, Research Policy 33(10): 14591476 .

BMBF (2000). Bundesbericht Forschung 2000, Bonn/Berlin.

BMBF (2004). Bundesbericht Forschung 2004, Bonn/Berlin.

BMBF (2005). Report of the Federal Government on Research 2004 - Abridged Version, Bonn/Berlin.

BMBF (2006a). Bundesbericht Forschung 2006, Bonn/Berlin.

BMBF (2006b). Die Hightech-Strategie für Deutschland, Bonn/Berlin.

BMBF and BMWA (2004). Innovation and Future Technologies for Medium-Sized Companies - High-Tech Master Plan, Bonn/Berlin.

BT-Drs. (1979). Bundesbericht Forschung VI, BT-Drs. 8/3024, Bonn.

BT-Drs. (1984). Bundesbericht Forschung 1984, BT-Drs. 10/1543, Bonn.

BT-Drs. (1988). Bundesbericht Forschung 1988, BT-Drs. 11/2049, Bonn.

BT-Drs. (1993). Bundesbericht Forschung 1993, BT-Drs. 12/5550, Bonn.

BT-Drs. (2005). Antwort der Bundesregierung; Entwicklung der Ausgaben für Forschung und Entwicklung des Bundes, insbesondere der Projektfördermittel, BT-Drs. 15/4809, Berlin. 
Busom, I. (2000). An empirical evaluation of the effects of R\&D subsidies, Economics of Innovation and New Technology 9(2): 111-148.

Czarnitzki, D. and Fier, A. (2002). Do Innovation Subsidies Crowd out Private Investment? Evidence from the German Service Sector, Konjunkturpolitik Applied Economics Quarterly 48(1): 1-25.

Czarnitzki, D. and Licht, G. (2006). Additionality of public R\&D grants in a transition economy, Economics of Transition 14(1): 101-131.

Czarnitzki, D., Ebersberger, B. and Fier, A. (2004). The Relationship between R\&D Collaboration, Subsidies and R\&D performance: Empirical Evidence from Finland and Germany, Discussion Paper No. 04-37, Zentrum für Europäische Wirtschaftsforschung (ZEW).

Duguet, E. (2004). Are R\&D subsidies a substitute or a complement to privately funded R\&D? Evidence from France using propensity score methods for nonexperimental data, Revue d'Economie Politique 114(2): 263-292.

Feldman, M. P. and Kelley, M. R. (2001). Winning an Award form the Advanced Technology Program: Pursuing R\&D Strategies in the Public Interest and Benefiting from a Halo Effect, NISTIR 657\%, National Institute of Standards and Technology.

Fier, A. (2002). Staatliche Förderung industrieller Forschung in Deutschland, Vol. 62 of ZEW Wirtschaftsanalysen, Nomos Verlagsgesellschaft.

Fryges, H. (2007). The Change of Sales Modes in International Markets: Empirical Results for German and British High-Tech Firms, Progress in International Business Research 1: 139-185.

González, X., Jaumandreu, J. and Pazó, C. (2005). Barriers to innovation and subsidy effectiveness, RAND Journal of Economics 36(4): 930-950.

Gouriéroux, C. (2000). Econometrics of Qualitative Dependent Variables, 2nd edn, Cambridge University Press.

Hall, B. (1990). The manufacturing sector master file: 1959-1987, NBER Working Paper Sereis No. 3366, Cambridge, MA.

King, G. and Zeng, L. (2001). Logistic Regression in Rare Events Data, Political Analysis 9(2): 137-163.

Lerner, J. (1999). The Government as Venture Capitalist: The Long-Run Impact of the SBIR Program, The Journal of Business 72(3): 285-318. 
Levin, R., Klevorick, A., Nelson, R. and Winter, S. (1987). Appropriating the Returns from Industrial Research and Development, Brookings Papers on Economic Activity 1987(3): 783-820.

Nguyen Van, P., Laisney, F. and Kaiser, U. (2004). The Performance of German Firms in the Business-Related Service Sector: A Dynamic Analysis, Journal of Business and Economic Statistics 22(3): 274-295.

OECD (2003). Science, Technology and Industry Scoreboard 2003, OECD.

Tanayama, T. (2007). Eligibility, awareness and the application decision: An empirical study of firm participation in an R\&D subsidy program, Discussion Paper No. 161, HECER.

Wallsten, S. J. (2000). The effects of government-industry R\&D programs on private R\&D: the case of the Small Business Innovation Research program, RAND Journal of Economics 31(1): 82-100. 


\section{Appendix}

Table 8: Overview and Aggregation of Industries

\begin{tabular}{|c|c|c|c|}
\hline \multicolumn{2}{|l|}{ Industry Sector } & \multicolumn{2}{|l|}{ Service Sector } \\
\hline Branches of Industry & NACE & Branches of Industry & NACE \\
\hline Manufacturing & & Knowledge intensive services & \\
\hline Textile & $17-19$ & Computer/telecomm. & $72,64.2$ \\
\hline Wood/paper/printing & $20-22$ & Technical services & $73,74.2-74.3$ \\
\hline Chemicals & $23-24$ & Consultancies & $74.1,74.4$ \\
\hline Plastic/rubber & 25 & & \\
\hline Glass/ceramics & 26 & & \\
\hline Metals & $27-28$ & & \\
\hline Machinery & 29 & & \\
\hline Electrical engineering & $30-32$ & & \\
\hline $\begin{array}{l}\text { Medical, precision, and } \\
\text { optical instruments }\end{array}$ & 33 & & \\
\hline Vehicles & $34-35$ & & \\
\hline Furniture/recycling & $36-37$ & & \\
\hline
\end{tabular}


Table 9: Transition Rates for Not Subsidized Firms in $t$ of the Sample

\begin{tabular}{rrrrr}
\hline \hline & \multicolumn{4}{c}{ Status in $t+1$} \\
\cline { 2 - 5 } Year & $\begin{array}{r}\text { No. of } \\
\text { obs. }\end{array}$ & Not & \\
\hline 1994 & 307 & 97.39 & 2.61 & 100.0 \\
1995 & 500 & 97.80 & 2.20 & 100.0 \\
1996 & 1,142 & 97.64 & 2.36 & 100.0 \\
1997 & 667 & 99.25 & 0.75 & 100.0 \\
1998 & 1,331 & 98.87 & 1.13 & 100.0 \\
1999 & 765 & 97.65 & 2.35 & 100.0 \\
2000 & 1,147 & 97.99 & 2.01 & 100.0 \\
2001 & 647 & 97.53 & 2.47 & 100.0 \\
2002 & 1,054 & 98.58 & 1.42 & 100.0 \\
2003 & 724 & 98.48 & 1.52 & 100.0 \\
2004 & 1,645 & 98.60 & 1.40 & 100.0 \\
\hline Total & 9,929 & 98.27 & 1.73 & 100.0 \\
\hline \hline
\end{tabular}

Table 10: Transition Rates for Subsidized Firms in $t$ of the Population and the Sample

\begin{tabular}{|c|c|c|c|c|c|c|c|c|}
\hline \multirow[b]{3}{*}{ Year } & \multicolumn{7}{|c|}{ Status in $t+1$} & \\
\hline & \multicolumn{4}{|c|}{ Population $^{a}$} & \multicolumn{4}{|c|}{ Sample } \\
\hline & $\begin{array}{c}\text { No. of } \\
\text { obs. }\end{array}$ & $\begin{array}{r}\text { Not } \\
\text { subs. }\end{array}$ & Subs. & Total & $\begin{array}{c}\text { No. of } \\
\text { obs. }\end{array}$ & $\begin{array}{l}\text { Not } \\
\text { subs. }\end{array}$ & Subs. & Total \\
\hline 1994 & 1,697 & 14.79 & 85.21 & 100.0 & 27 & 14.81 & 85.19 & 100.0 \\
\hline 1995 & 1,875 & 27.04 & 72.96 & 100.0 & 35 & 31.43 & 68.57 & 100.0 \\
\hline 1996 & 1,816 & 16.85 & 83.15 & 100.0 & 91 & 4.40 & 95.60 & 100.0 \\
\hline 1997 & 2,010 & 16.17 & 83.83 & 100.0 & 66 & 13.64 & 86.36 & 100.0 \\
\hline 1998 & 2,039 & 17.85 & 82.15 & 100.0 & 98 & 17.35 & 82.65 & 100.0 \\
\hline 1999 & 2,234 & 20.77 & 79.23 & 100.0 & 62 & 20.97 & 79.03 & 100.0 \\
\hline 2000 & 2,399 & 22.72 & 77.28 & 100.0 & 177 & 20.34 & 79.66 & 100.0 \\
\hline 2001 & 2,738 & 10.04 & 89.96 & 100.0 & 83 & 6.02 & 93.98 & 100.0 \\
\hline 2002 & 3,180 & 16.13 & 83.87 & 100.0 & 299 & 12.71 & 87.29 & 100.0 \\
\hline 2003 & 3,062 & 25.80 & 74.20 & 100.0 & 172 & 20.93 & 79.07 & 100.0 \\
\hline 2004 & 2,677 & 26.04 & 73.96 & 100.0 & 213 & 28.17 & 71.83 & 100.0 \\
\hline Total & 25,727 & 19.58 & 80.42 & 100.0 & 1,323 & 17.61 & 82.39 & 100.0 \\
\hline
\end{tabular}

Notes: ${ }^{a}$ The population is calculated from the PROFI database. Only firms which are subsidized in $t$ are considered. Contract research is not included. 
Figure 4: Predicted Probability of Transition

Transition:

not subsidized $\rightarrow$ subsidized $(0 \rightarrow 1)$

Predicted probability

in dependence of the number of employees

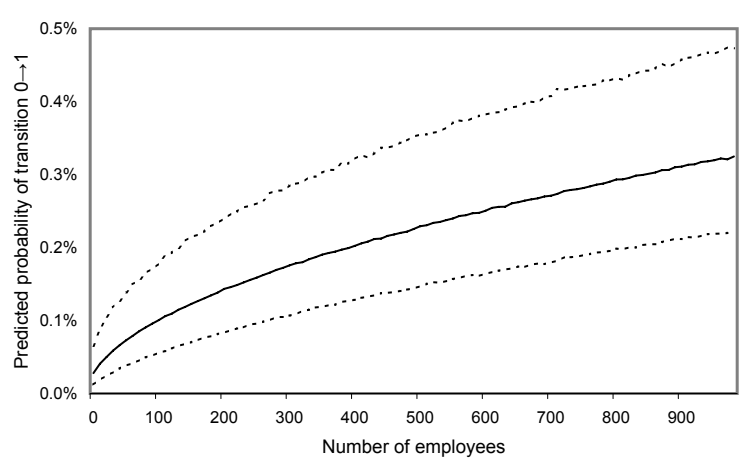

Predicted probability

in dependence of the qualification

(share of employees with a university degree)

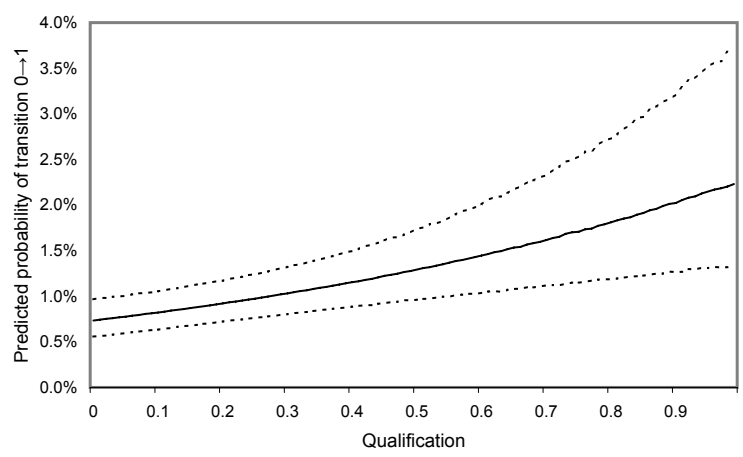

Transition:

subsidized $\rightarrow$ newly subsidized $(1 \rightarrow 1)$

Predicted probability

in dependence of the number of employees

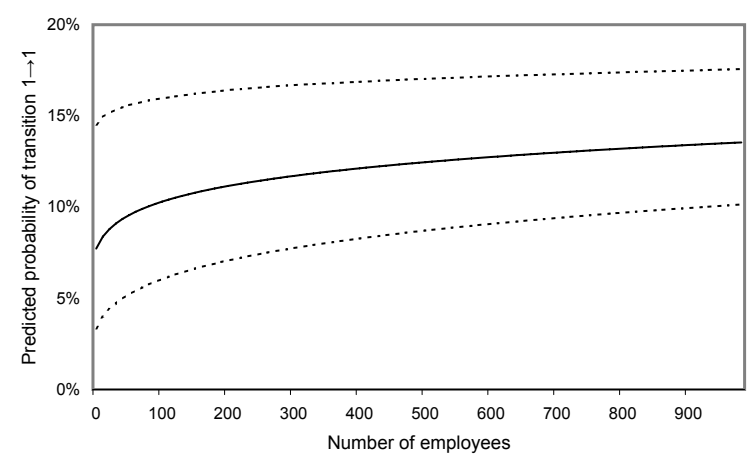

Predicted probability

in dependence of the experience

(no. of approved projects in the last 5 years)

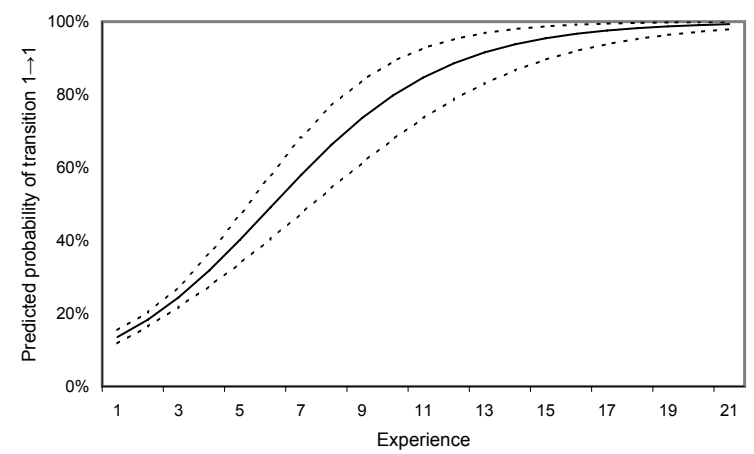

Solid line: predicted probability of transition in dependence of the specific variable, all other variables set to their mean.

Dotted lines: simulated $90 \%$ confidence interval for the predicted probability of transition, using 10,000 simulations. Source: own calculations. 
Table 11: Regression Results for the Sub-sample (Coefficients are shown)

\begin{tabular}{|c|c|c|c|c|}
\hline \multirow[b]{2}{*}{ Variable } & \multicolumn{2}{|c|}{$\begin{array}{c}\text { Not subsidized } \rightarrow \text { subsidized } \\
\text { Rare events logit model }\end{array}$} & \multicolumn{2}{|c|}{$\begin{array}{c}\text { Subsidized } \rightarrow \text { newly subsidized } \\
\text { Logit model }\end{array}$} \\
\hline & (a) & (b) & (c) & (d) \\
\hline Continuation $_{t+1}$ & & & 0.287 & 0.285 \\
\hline Experience $_{\text {since } t-4}$ & $1.061^{* * *}$ & $1.047^{* * *}$ & $0.354^{* * *}$ & $0.353^{* * *}$ \\
\hline Exp_EU ${ }_{\text {since } t-2}$ & 0.406 & 0.406 & $0.487^{* *}$ & $0.495^{* * *}$ \\
\hline Exp_regional $_{\text {since } t-2}$ & 0.394 & 0.381 & 0.019 & 0.023 \\
\hline Sub_supply $t+1$ & $0.041^{* *}$ & $0.041 * *$ & $0.051^{* *}$ & $0.052^{* *}$ \\
\hline Log(Employees) & $0.540 * * *$ & $0.533^{* * *}$ & $0.249 * * *$ & $0.238^{* * *}$ \\
\hline Employees_change & 0.041 & 0.048 & $1.206^{* * *}$ & $1.197^{* * *}$ \\
\hline Log(Age) & -0.026 & -0.029 & -0.027 & -0.028 \\
\hline R\&D_occ & $0.722^{*}$ & $0.725^{*}$ & & \\
\hline R\&D_con & $1.207^{* * *}$ & $1.207 * * *$ & 0.321 & 0.315 \\
\hline Qualification & $1.519^{* * *}$ & $1.511^{* * *}$ & $0.742^{*}$ & $0.710^{*}$ \\
\hline Patent_stock_dev & & 0.006 & & 0.004 \\
\hline Group_national & $-0.396^{*}$ & $-0.400^{*}$ & -0.269 & -0.266 \\
\hline Group_foreign & -0.486 & -0.480 & -0.240 & -0.245 \\
\hline East & 0.060 & 0.064 & $0.601^{* * *}$ & $0.603^{* * *}$ \\
\hline Constant & $-7.997 * * *$ & $-7.955^{* * *}$ & $-4.482^{* * *}$ & $-4.427^{* * *}$ \\
\hline No. of obs. & 7,560 & 7,560 & 938 & 938 \\
\hline Wald $\chi_{\text {all }}^{2}$ & $182.04^{* * *}$ & $191.76^{* * *}$ & $100.37^{* * *}$ & $100.22^{* * *}$ \\
\hline Log-Likelihood & & & -439.047 & -438.951 \\
\hline Mc Fadden's $R^{2}$ & & & 0.154 & 0.154 \\
\hline
\end{tabular}

Notes: $* * *(* *, *)$ indicate significance level of $1 \%(5 \%, 10 \%)$. Unless otherwise specified, the variables refer to time $t$. Standard errors are clustered because almost $50 \%$ of the firms are more than once in the sample. Industry and year dummies are not included since they are not jointly significant. 
Table 12: Regression Results for Sub-samples (Coefficients are shown)

\begin{tabular}{|c|c|c|c|c|c|c|c|c|c|c|}
\hline \multirow[b]{3}{*}{ Variable } & \multicolumn{5}{|c|}{$\begin{array}{c}\text { Not subsidized } \rightarrow \text { subsidized } \\
\text { Rare even logit model }\end{array}$} & \multicolumn{5}{|c|}{$\begin{array}{c}\text { Subsidized } \rightarrow \text { newly subsidized } \\
\text { Logit model }\end{array}$} \\
\hline & \multicolumn{3}{|c|}{ Firm size ${ }^{a}$} & \multicolumn{2}{|c|}{ Firm location } & \multicolumn{3}{|c|}{ Firm size ${ }^{a}$} & \multicolumn{2}{|c|}{ Firm location } \\
\hline & Small & Medium & $\overline{\text { Large }}$ & West & East & Small & Medium & $\overline{\text { Large }}$ & West & East \\
\hline Continuation $_{t+1}$ & & & & & & 0.547 & 0.159 & 0.152 & 0.143 & $0.654^{*}$ \\
\hline Experience $_{\text {since }} t-4$ & $1.359^{* * *}$ & $1.430 * * *$ & $1.012^{* * *}$ & $1.265^{* * *}$ & $1.202^{* * *}$ & $0.309^{*}$ & $0.451^{* * *}$ & $0.316^{* * *}$ & $0.413^{* * *}$ & $0.293^{* * *}$ \\
\hline Exp_EU since $t-2$ & 0.779 & 0.397 & 0.528 & $0.740^{* *}$ & 0.286 & 0.348 & -0.053 & $0.686^{*}$ & 0.237 & $0.386^{*}$ \\
\hline Exp_regional $_{\text {since } t-2}$ & 0.009 & $0.840^{* *}$ & 0.179 & $0.756^{* * *}$ & 0.059 & 0.363 & 0.165 & -0.161 & 0.222 & 0.239 \\
\hline Sub_supply $_{t+1}$ & $0.084^{*}$ & 0.032 & $0.071^{* *}$ & $0.076^{* * *}$ & -0.007 & 0.053 & 0.005 & 0.080 & $0.056^{* *}$ & 0.016 \\
\hline Log(Employees) & 0.437 & $0.588^{* * *}$ & 0.182 & $0.560^{* * *}$ & $0.439^{* * *}$ & $0.570^{* *}$ & $0.537^{* * *}$ & $0.536^{* *}$ & $0.234^{* * *}$ & 0.026 \\
\hline Employees_change & 0.149 & 0.410 & -0.039 & 0.269 & 0.073 & 0.850 & 0.627 & 1.111 & 0.561 & $1.334^{* *}$ \\
\hline Log(Age) & $-0.373^{* *}$ & 0.024 & -0.009 & 0.033 & -0.174 & -0.186 & -0.033 & 0.079 & -0.034 & -0.094 \\
\hline R\&D_occ & $1.483^{*}$ & 0.716 & 0.735 & $0.923^{*}$ & $1.244^{*}$ & & & & & \\
\hline R\&D_con & $1.400^{*}$ & $0.876^{*}$ & 1.469 & $1.260^{* * *}$ & $1.511^{* *}$ & 0.857 & 0.508 & -0.070 & 0.620 & 0.321 \\
\hline Qualification & $1.738^{* * *}$ & $1.567 * * *$ & -0.292 & $1.160^{* * *}$ & $1.071^{* *}$ & 0.710 & $0.810^{*}$ & 1.275 & $1.118^{* *}$ & 0.404 \\
\hline Group_national & -0.577 & -0.163 & -0.371 & $-0.383^{*}$ & -0.071 & 0.197 & -0.153 & -0.531 & -0.106 & 0.062 \\
\hline Group_foreign & & $-0.832^{*}$ & -0.623 & $-0.805^{* *}$ & -0.274 & & -0.429 & 0.366 & -0.415 & 0.208 \\
\hline East & -0.017 & 0.236 & 0.081 & & & $0.616^{*}$ & $0.466^{*}$ & 0.633 & & \\
\hline Constant & $-7.439 * * *$ & $-8.436 * * *$ & $-5.387 * * *$ & $-8.588 * * *$ & $-7.077^{* * *}$ & $-5.885^{* * *}$ & $-5.904 * * *$ & $-7.432^{* * *}$ & $-4.648^{* * *}$ & $-3.024 * * *$ \\
\hline No. of obs. & 4,292 & 4,539 & 1,098 & 6,603 & 3,326 & 423 & 541 & 359 & 891 & 432 \\
\hline Transition rate & 0.68 & 1.81 & 5.56 & 1.76 & 1.68 & 20.1 & 22.0 & 25.1 & 19.3 & 28.2 \\
\hline Wald $\chi_{\text {all }}^{2}$ & $53.76^{* * *}$ & $115.46^{* * *}$ & $31.18^{* * *}$ & $175.24^{* * *}$ & $81.08^{* * *}$ & $55.85^{* * *}$ & $68.32^{* * *}$ & $96.56^{* * *}$ & $118.17^{* * *}$ & $45.41^{* * *}$ \\
\hline Wald $\chi_{\text {year }}^{2}$ & & & & & & & & $29.26^{* * *}$ & $25.83^{* * *}$ & \\
\hline Log-Likelihood & & & & & & -178.992 & -237.772 & -154.725 & -354.952 & -224.630 \\
\hline Mc Fadden's $R^{2}$ & & & & & & 0.157 & 0.166 & 0.235 & 0.188 & 0.126 \\
\hline
\end{tabular}

Notes: ${ }^{a}$ Small firms have 50 employees or less, medium-sized firms between 51 and 500 employees and large firms more than 500 employees. ${ }^{* * *}(* *, *)$ indicate significance level of $1 \%(5 \%, 10 \%)$. In the regressions for small firms the foreign variable is excluded since no small firm which is foreign-owned get a newly subsidized project. Unless otherwise specified, the variables refer to time $t$. Standard errors are clustered because almost $50 \%$ of the firms participate more than once. Year dummies are included in the regressions if they are jointly significant. 